\title{
Dynamics of single-barred embayed beaches
}

\author{
Elena Ojeda ${ }^{\text {a,c }}$, Jorge Guillén a,c,*, Francesca Ribas b,c,1 \\ a Instituto de Ciencias del Mar, CSIC. Paseo Marítimo de La Barceloneta, 37-49. 08003, Barcelona, Spain

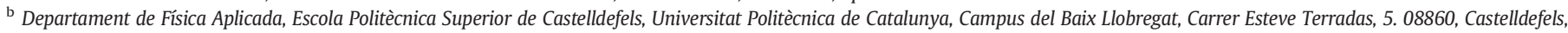 \\ Barcelona, Spain \\ c Unidad Asociada UPC-CSIC Geología, Morfodinámica y Gestión Costera, Barcelona, Spain
}

\section{A R T I C L E I N F O}

\section{Article history:}

Received 23 July 2010

Received in revised form 2 December 2010

Accepted 5 December 2010

Available online 14 December 2010

Communicated by J.T. Wells

\section{Keywords:}

subtidal sand bar

nearshore morphodynamics

video imagery

artificial beach

Barcelona

Mediterranean

\begin{abstract}
A B S T R A C T
The dynamics of single submerged sandbars of two artificial embayed beaches (La Barceloneta and Bogatell, Barcelona, NW Mediterranean) has been studied with a video-recorded data set of 4.3 years. The alongshoreaveraged cross-shore migration, the orientation with respect the shoreline and the sinuosity of the barlines have been analyzed and related to wave conditions, alongshore sediment transport and shoreline variability. In general, the submerged bars follow the general cyclic morphological behaviour observed in natural beaches, switching among the four intermediate morphodynamic states, but the studied beaches can be arrested during long periods of low wave conditions. The dominant up-state transition in Barcelona beaches during storms is the transition toward the rhythmic bar and beach state, the complete morphodynamic reset (longshore bar and trough state) only occurring during extreme wave events. The cross-shore migration of bars is dominated by the weekly and interannual components. The interannual component shows an onshore bar migration trend at both beaches, in contrast with the net offshore migration observed in multibarred open beaches. Bar disposition is located progressively seaward in the dominant alongshore transport direction (i.e., oblique with respect to the shoreline). At La Barceloneta beach, shoreline and barline orientations change consistently and a significant correlation between the accumulated alongshore sediment transport and the associated change in bar orientation has been found, suggesting that alongshore transport can play a significant role in barline orientation. Finally, bar sinuosity increases during eastern storms in both beaches. This indicates that the formation of crescentic bars occurs for approximately shore-normal waves. Some of the differences observed in bar morphology and mobility in the two studied beaches are related to their different level of protection with respect to the incident waves (beach indentation).
\end{abstract}

(c) 2010 Elsevier B.V. All rights reserved.

\section{Introduction}

Subtidal shore-parallel sandbars are a common feature in a variety of nearshore environments, from high-energy to protected coasts, from microtidal to macrotidal regimes and in swell- or wave-dominated settings (Wijnberg and Kroon, 2002). The number of sandbars can vary between one and four, depending on the site, the conditions and the configuration of the beach, and they can show either an alongshoreuniform shape or a crescentic shape, with undulations at scales of hundreds of metres (Van Enckevort and Ruessink, 2003b).

Shore-parallel bars are dynamic morphological features that can migrate along- and across-shore, depending on the wave conditions. Alongshore bar migration, probably driven by the alongshore current,

\footnotetext{
* Corresponding author. Instituto de Ciencias del Mar, CSIC. Paseo Marítimo de La Barceloneta, 37-49. 08003, Barcelona, Spain. Tel.: + 34 932309600; fax: + 34932309555 E-mail addresses: eojeda@icm.csic.es (E. Ojeda), jorge@icm.csic.es (J. Guillén), francesca.ribas@upc.edu (F. Ribas).

1 Tel.: + 34934134145 .
}

has been described by means of the migration of rips or crescentic shapes in bars, with rates of the order of $10 \mathrm{~m}$ /day (see Table 1 in Van Enckevort and Ruessink, 2003b). Cross-shore bar migration has been described at different time scales. At short time scales, bars undergo offshore migration during high-energy wave conditions, when the wave height-water depth ratio is large and the undertow current (nearbottom, breaking wave-driven steady flow) is dominant (e.g., Plant et al., 2001). Onshore bar migration occurs as the wave height-water depth ratio decreases, during intermediate wave conditions. In these cases, the undertow is less intense and the cross-shore sediment transport is mainly due to wave non-linearity (wave skewness and wave asymmetry, see Plant et al., 2001). At longer time scales, multibarred beaches often show a net offshore migration (NOM) pattern (Shand et al., 1999). This interannual behaviour involves: 1) the generation of the bar near the shore (at approximately 1 to $2 \mathrm{~m}$ depth); 2 ) onshore and offshore migration of the bars according to wave conditions but with a net offshore migration through the surf zone; and 3 ) bar decay at the seaward margin of the nearshore, prompting the formation of a new bar near the shoreline (starting the process at 1). There is a wide inter-site variation in the duration of this cycle, from 
1 year at Hasaki in Japan (Kuriyama, 2002) to more than 10 years in Poland (Rozynski, 2003) or the Netherlands (Ruessink and Kroon, 1994; Wijnberg and Terwindt, 1995). Ruessink et al. (2009) distinguished between interannual NOM (an approximately uniform migration associated to sea-dominated coasts) and episodic NOM (steered by storm events in swell-dominated coasts). Although less frequently, a net onshore migration of bar systems at interannual scales has been also observed in some beaches (Aagaard et al., 2004). Finally, no net longterm migration patterns have been documented for single barred beaches.

The cross-shore migration of bars is strongly related with changes in the 3D configuration of the morphology. The changes in the plan-view shape of barred beaches were described in detail by Wright and Short (1984), since they were essential features of their beach state classification. A shore-parallel bar (longshore bar and trough state) is developed or enlarged during the peak of a storm, as the bar migrates offshore. Under the subsequent lower energetic conditions, the bar becomes crescentic and migrates slowly onshore (rhythmic bar and beach state) until the horns occasionally weld to the shore (transverse bar and rip state). If low wave energy continues, the bar attaches completely to the shore (low tide terrace state) and the beach finally reaches a non-barred configuration (reflective state). This accretionary sequence can be disturbed by an increase in wave height, which will cause the beach to accommodate to the higher waves by evolving rapidly towards the longshore bar and trough state. Furthermore, a certain bar morphology can be "arrested" under very low wave conditions, when the wave energy is too low to cause sediment transport (Aagaard, 1998).

Most studies on bar dynamics have dealt with open beaches and multiple barred beaches. For instance, the long sandy beaches with one or two sandbars at Duck, USA, and Hasaki, Japan, have been described by Kuriyama (2002) and Sallenger et al. (1985), respectively. Examples of long sandy beaches with multiple bars are Terschelling, the Netherlands (Ruessink and Kroon, 1994), Wanganui, New Zealand (Shand et al., 1999), the Ebro Delta, Spain (Guillén and Palanques, 1993) and the beach barrier of Thau Lagoon, France (Barusseau et al., 1994). Single- barred embayed beaches, however, have received less attention. There are studies related to rips such as Short (1985) (Narrabeen beach, Australia) and Holman et al. (2006) (Palm Beach, Australia), short-term studies on bar migration such as Van Maanen et al. (2008) (Tairua beach, New Zealand), and studies on beach morphodynamics such as Ranasinghe et al. (2004) (Palm Beach, Australia).

The dynamics of barred beaches in the Mediterranean have been mainly studied at time scales ranging from days to several months (Bowman and Goldsmith, 1983; Guillén and Palanques, 1993). The limited number of long-term morphological series on the Mediterranean does not clearly suggest the occurrence of a net onshore/offshore migration pattern. On the Ebro Delta, a two year study suggested a net onshore bar migration pattern due to the development of a new outer bar and the onshore migration of the inner bar to weld onto the beach (Guillén and Palanques, 1993). At longer time scales ( 10 years), several authors have found offshore migration of multiple-bar systems on the French Mediterranean coast, but it has been related to the advance of the shoreline (Sabatier and Provansal, 2000) or to the effect of individual storms with long return periods (Certain and Barusseau, 2005).

In this study, we analyze the morphological evolution of the subtidal sandbars of two of the artificial embayed beaches of the Barcelona city coast (NW Mediterranean; Fig. 1) during 4.3 years. These two beaches are subject to the same climatic conditions but have different characteristics (morphology of the submerged sand bar, slope, orientation, sediment availability, length and level of indentation). In a previous paper, Ojeda and Guillén (2008) analyzed the evolution of the shoreline of the Barcelona city area from November 2001 to December 2004. At La Barceloneta and Bogatell they found a retreating trend temporally alleviated by the artificial nourishment of the emerged beach in summer 2002 and by a sand relocation in La Barceloneta in summer 2004. At shorter time-scales, Ojeda and Guillén (2008) highlighted the importance of the beach response to storm events (producing beach rotation or local erosion or accretion) in the beach evolution and they also suggested the existence of a certain coupling between the bar and the shoreline, i.e.,

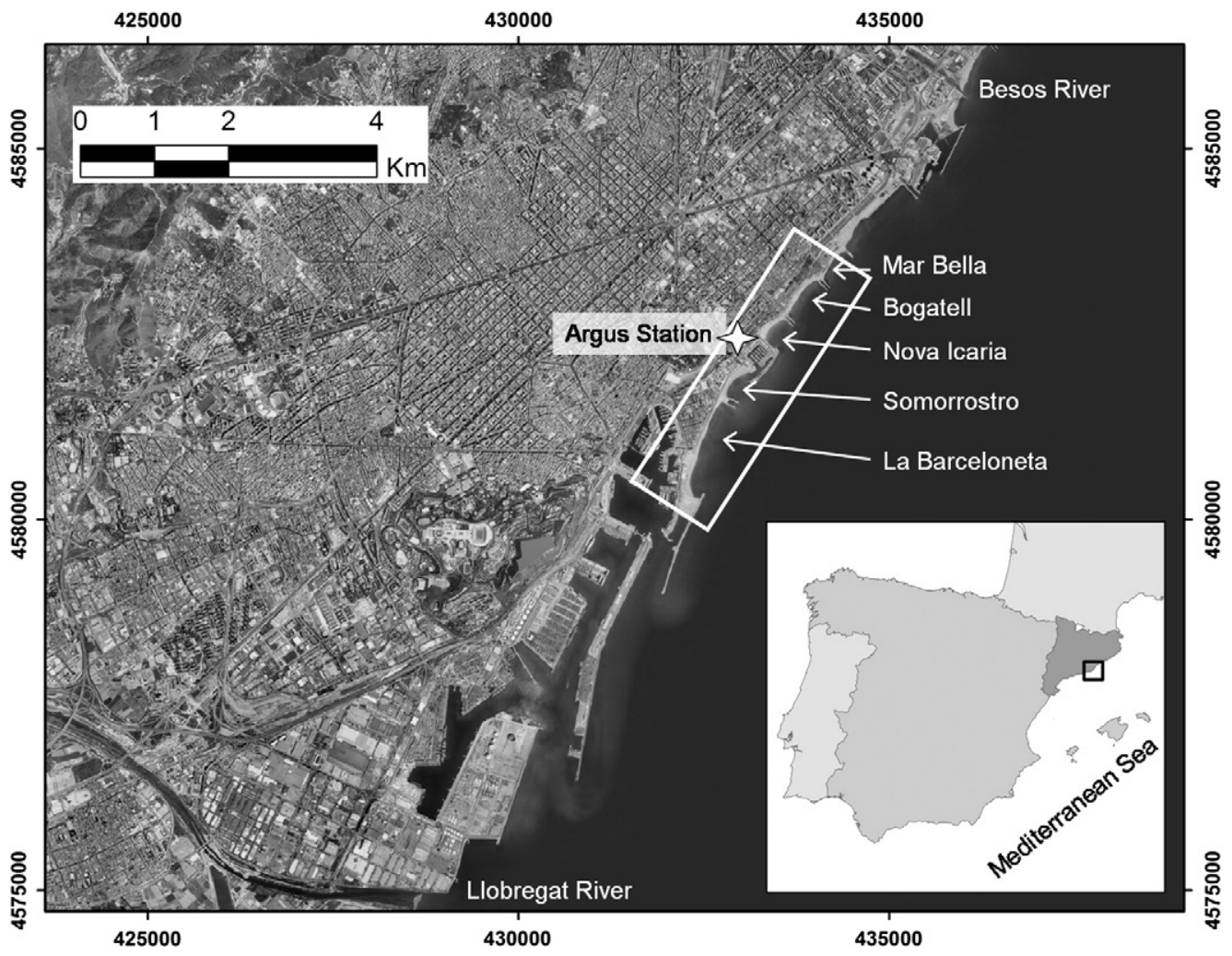

Fig. 1. Study area with the location of the Argus station. The white rectangle indicates the area visible with the video cameras. 
an interrelation between the bar and the shoreline behaviours. Recently, Ribas et al. (2010) carried out a comparative analysis between bathymetric surveys and video observations that confirmed the suitability of using video images to monitor the subtidal sandbars present along La Barceloneta and Bogatell beaches.

The aim of the present study is to characterize the evolution of the bars of the two Barcelona beaches and its correlation with wave conditions at different time-scales in order to enhance our rudimentary understanding of the morphodynamics of single barred embayed beaches. Since there are no previous studies of bar behaviour at the Barcelona coast, we will present here a general overview of the bar characteristics. We will first consider the alongshore uniform behaviour at different time scales (Section 5). Subsequently, we will describe the 3D characteristics, such as bar orientation, bar sinuosity and beach states (Section 6). Finally, the interpretation of the observed behaviour, including an analysis of the differences and similarities found between the two studied beaches and a comparison with natural beaches, will be considered in the discussion (Section 7).

\section{Field site}

Barcelona is located on the north-eastern coast of Spain (NW Mediterranean, see Fig. 1). In this region the tidal range can be considered negligible (about $0.2 \mathrm{~m}$ ), and the waves are the main hydrodynamic force acting on the beaches. Statistical analysis of wave conditions in the region from 1984 to 2004 shows an offshore mean significant wave height of $0.70 \mathrm{~m}$, with maximum wave heights of $7.80 \mathrm{~m}$ and an averaged mean period of $4.3 \mathrm{~s}$ (Gómez et al., 2005). Storms occur mainly from October to April and the most important ones are those coming from the east and northeast.

The Coastal Monitoring Station of Barcelona focuses on four embayed beaches (Fig. 1) ranging from 400 to $1100 \mathrm{~m}$ length and showing different orientations. An Argus video system (Holman and Stanley, 2007) has been used to study the beaches and the submerged sandbars since October 2001. Five cameras located at 142-m height offer a $180^{\circ}$ view of the littoral zone (see Ojeda and Guillén (2008) for a more detailed description). Fig. 2 is a plan view of the study area obtained after rectifying and merging the 10-minute exposure images of the five cameras. The accuracy of the photogrammetric transformation from image to ground coordinates is typically 1 pixel. The pixel size ranges from 1 to $1.5 \mathrm{~m}$ in the cross-shore direction and from 1 to $20 \mathrm{~m}$ in the alongshore direction. The worst resolution is found for the alongshore direction at the southern end of La Barceloneta, where 1 pixel corresponds to some $20 \mathrm{~m}$ alongshore; at the northern limit of Bogatell 1 pixel corresponds to approximately $10 \mathrm{~m}$ alongshore. This study comprises 4.3 years of data, from November 2001 to March 2006. During these years only a small number of gaps due to technical problems can be found in the video image data, and these time gaps always lasted less than a week.

As can be seen in Fig. 2, Barcelona beaches are separated by double shore-perpendicular dikes, with the exceptions of Nova Icaria and Somorrostro, which are separated by the Olympic Marina, and the southern limit of La Barceloneta, which is an L-shape groin. Furthermore,
Table 1

Morphological characteristics of the four beaches visible at the plan view of Fig. 2.

\begin{tabular}{lllll}
\hline & La Barceloneta & Somorrostro & Nova Icaria & Bogatell \\
\hline Length & 1100 & 400 & 400 & 600 \\
Beach orientation $^{\mathrm{a}}$ & $20^{\circ}$ & $32^{\circ}$ & $47^{\circ}$ & $38^{\circ}$ \\
Slope $^{\mathrm{b}}$ & 0.031 & 0.036 & 0.049 & 0.031 \\
$\mathrm{~d}_{50}{ }^{\circ}$ & $900 \mu \mathrm{m}$ & $450 \mu \mathrm{m}$ & $660 \mu \mathrm{m}$ & $770 \mu \mathrm{m}$ \\
No. bars & 1 & 0 & 0 & 1 \\
\hline
\end{tabular}

a Mean orientation of the shoreline with respect to the north.

b Mean slopes along the beaches (at the different transects) obtained from 0 to $5 \mathrm{~m}$ depth from two bathymetric surveys carried out in October and November 2003.

c Sediment sampled at the swash zone.

the northern dike of Nova Icaria continues as a submerged oblique breakwater several tens of metres long (visible in Fig. 2 due to waves breaking over it). Table 1 summarizes the morphological characteristics of the four beaches visible at the plan view of Fig. 2. The grain size of the sediment (d50) on these beaches ranges between $430 \mu \mathrm{m}$ (at 5 meter depth) and $1500 \mu \mathrm{m}$ (on the dry beach). This study is focused on La Barceloneta and Bogatell beaches because the other beaches display a featureless profile within the active surf zone. Three bathymetric surveys of the area during the study period showed that, in general, La Barceloneta presented a more developed bar than Bogatell, which exhibited a more terraced shape (without a trough, Fig. 3). In autumn 2003, the bar at La Barceloneta was located $80 \mathrm{~m}$ from the shoreline (at $2 \mathrm{~m}$ water depth on average), whilst the bar at Bogatell was located $50 \mathrm{~m}$ offshore from the shoreline, at $1.5 \mathrm{~m}$ depth. Bogatell beach has a higher level of indentation (the ratio between the lateral groin length and the beach length), and thereby it shows a higher degree of protection against wave action.

Two main human interventions took place at these two beaches during the study period. An artificial nourishment of the emerged beach of La Barceloneta and Bogatell was made in summer 2002 and sand was relocated in La Barceloneta in summer 2004. The nourishment of La Barceloneta involved the addition of approximately $40,000 \mathrm{~m}^{3}$ of sand in the $350-\mathrm{m}$ northern section of the beach and produced a mean advance of the shoreline of $14 \mathrm{~m}$ in the nourished section. The nourishment of Bogatell involved the addition of $70,000 \mathrm{~m}^{3}$ of sand along the entire beach and caused a mean advance of the shoreline of $20 \mathrm{~m}$. At both beaches, the nourishments had a transitory effect on the shoreline, as described by Ojeda and Guillén (2006, 2008). The sand relocation at La Barceloneta on summer 2004 implied the movement of approximately $30,000 \mathrm{~m}^{3}$ of sand from the back section of the southern limit of the beach to the northern limit of the beach. This intervention had a confined effect in time and space on the shoreline that lasted for less than six months, as by the end of 2004 erosion was again visible on that side of the beach (Ojeda and Guillén, 2008).

\section{Methodology}

\subsection{Shoreline and barline extraction}

Ojeda and Guillén (2008) examined the shoreline evolution of La Barceloneta and Bogatell beaches from November 2001 to December

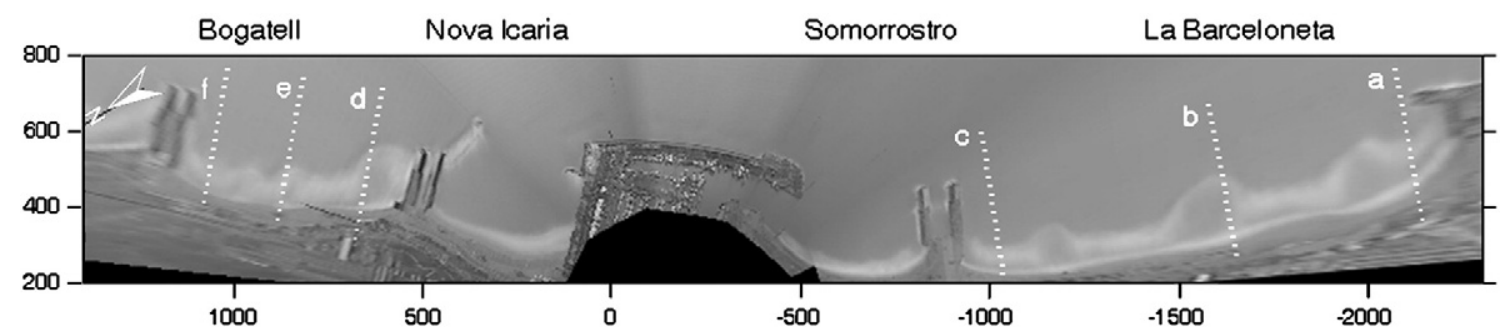

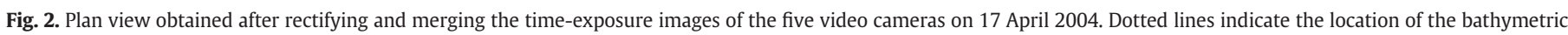
profiles presented in Fig. 3. 


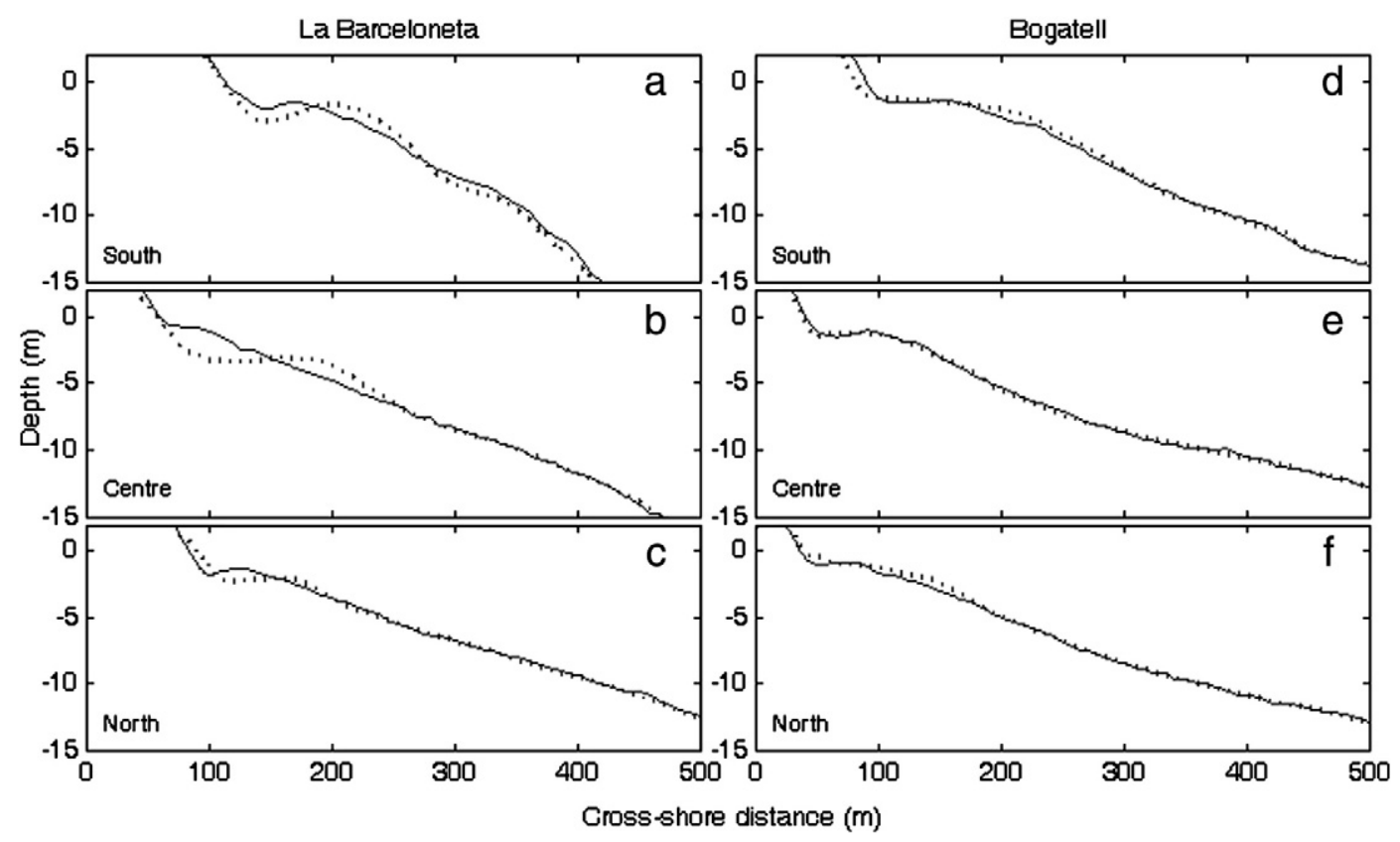

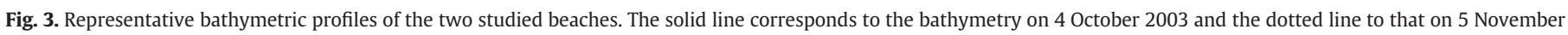
2003. See profile locations in Fig. 2.

2004. In the present study the extraction of the new shorelines in 2005 and 2006 from the time-exposure video images was done following the same procedure. The reference shorelines defined for La Barceloneta and Bogatell beaches in the previous study were also used here. The mean cross-shore discrepancies between video and differential Global Positioning System (dGPS) surveyed shorelines (averaged alongshore without regarding the sign of the difference) were $4.70 \mathrm{~m}$ at La Barceloneta and $2.88 \mathrm{~m}$ at Bogatell (Ojeda and Guillén, 2008).

Sandbars were inferred from the rectified time-exposure video images. The rectified video images extended $600 \mathrm{~m}$ in the cross-shore direction and $3.7 \mathrm{~km}$ in the alongshore direction (Fig. 2). The mapping of the sandbars is based on the preferential wave breaking over shallow areas and requires the occurrence of a certain wave height range. This range varies depending on the depth of the bar crest. The minimum $\mathrm{H}_{\mathrm{s}}$ which allowed for bar tracking during this study period was $0.74 \mathrm{~m}$. When $\mathrm{H}_{\mathrm{s}}$ was larger than approximately $3 \mathrm{~m}$ the breaking zone occupied the entire nearshore, hindering barline detection. Gaps in the barline dataset were mostly due to low wave energy resulting in the absence of a clear wave-breaking pattern.

When $\mathrm{H}_{\mathrm{s}}$ is adequate, the bars are seen in the time-exposure image as a bright line due to the presence of wave foam, contrasting with darker regions where wave breaking does not occur (Fig. 2). The bars were extracted from every image showing a clear breakerline through an automated alongshore tracking of the intensity maxima across each beach section (Pape et al., 2010). These lines (referred to as barlines) were smoothed alongshore using a Hanning window to remove the noise due to the pixel variability. The half-width of the Hanning window was $30 \mathrm{~m}$ at Bogatell, and at La Barceloneta it was changed from $50 \mathrm{~m}$ before January 2005 to $25 \mathrm{~m}$ thereafter (when the size of the crescentic shapes of the bar became shorter). Finally, the barlines were checked visually and incorrect sections were manually removed. The location of each bar was stored in a matrix $[X(\mathrm{y}, \mathrm{t})]$ that contained the bar crest cross-shore location with respect to the reference shoreline, $\mathrm{X}$, at time $\mathrm{t}$ and alongshore location $\mathrm{y}$.

\subsection{Morphological descriptors}

The alongshore-averaged bar location $\left[\mathrm{X}_{\mathrm{y}}(\mathrm{t})\right]$ was calculated by averaging each barline over the extent of the corresponding beach.
Incomplete barlines with less than $80 \%$ of the length of the bar visible were eliminated from the alongshore-averaged cross-shore location data set. The lack of a section of bar could be due to an absence of wave breaking over the bar or to the attachment of a bar section to the shoreline (a typical case in the northern section of Bogatell beach).

Time series of alongshore-averaged locations obtained from video images include the apparent migration of the bars produced by changes in the tide level and the wave conditions. Ribas et al. (2010) found that alongshore-averaged cross-shore bar position at La Barceloneta and Bogatell differed from real bar crest location by a distance of 10-15 m. Apparent barline variability was mainly due to offshore wave height changes whilst the effect of changes in the tide level was negligible. Following their suggestion, the alongshoreaveraged location of the bars was only sampled during a specific range of $\mathrm{H}_{\mathrm{s}}$ in order to reduce the variability induced by changes in the wave conditions. Alongshore-averaged locations were calculated for those data within a $1 \mathrm{~m} \mathrm{H}_{\mathrm{s}}$ range: a $\mathrm{H}_{\mathrm{s}}$ lower than $2.00 \mathrm{~m}$ at La Barceloneta and lower than $1.75 \mathrm{~m}$ at Bogatell.

The entire procedure used to obtain alongshore-averaged locations (i.e., exclusion of incomplete barlines and sampling only during a 1-m wave height range) implied a loss of $44 \%$ of the barline dataset in La Barceloneta and 45\% in Bogatell. Ribas et al. (2010) showed that, following this procedure, the cross-shore barline position was established with an accuracy of $11 \mathrm{~m}$ in Bogatell and $14 \mathrm{~m}$ in La Barceloneta.

The time series of the alongshore-averaged location of each beach was decomposed into an interannual $\left[\mathrm{X}_{\mathrm{ia}}(\mathrm{t})\right]$, a seasonal $\left[\mathrm{X}_{\mathrm{s}}(\mathrm{t})\right]$ and a weekly $\left[\mathrm{X}_{\mathrm{w}}(\mathrm{t})\right]$ component [for computational details see Van Enckevort and Ruessink (2003a)]. The seasonal component essentially encompasses the response of the sandbars to the seasonal variability in wave height (higher-energy winter months versus lower-energy summer months), while the weekly component contains the bar response to individual storms and to groups of storms, together with the measurement noise.

The best-fit linear line corresponding to each barline and to each shoreline was used to calculate the bar orientation and the shoreline orientation, respectively. Alongshore non-uniformities in the bars were quantified with the daily-averaged sinuosity (Fig. 4), defined as the ratio between the total length of the barline and the distance between its two ends following a straight line (Ojeda et al. 2008). This quantity is a measurement of the presence of crescentic features along 


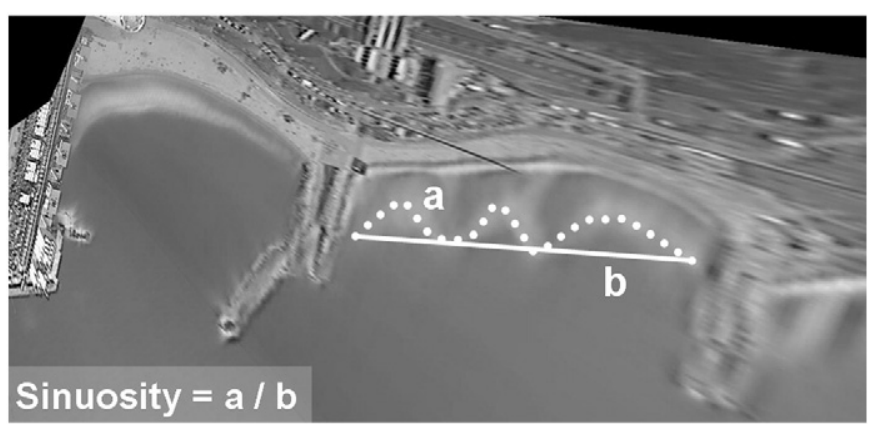

Fig. 4. Sketch representing the sinuosity calculation.

the bar. The orientation and the sinuosity of the barlines were also obtained only for the complete barlines (i.e., excluding those barlines with less than $80 \%$ of the length of the bar visible).

\section{Wave data}

Wave data were obtained from two sources: measurements from a directional buoy placed at deep water in front of the Llobregat River mouth and the results of the WANA model data set (node WANA2066051). The WANA data is computed by the Spanish National Institute of Meteorology using the HIRLAM and WAM numerical models (Spanish Port Authority, http://www.puertos.es). Before February 2004, the Llobregat buoy was scalar and only the WANA model provided directional wave information every three hours. The WANA data set was calibrated through linear regression in order to use it to complete the directional information when the Llobregat buoy was scalar and to fill in gaps in the overall wave measurements (only gaps longer than 12 hours were filled in). The calibration process was done for two different time spans. The directions were calibrated using data from February 2004 to January 2007, whilst for the calibration of the $\mathrm{H}_{\mathrm{s}}$ the period was from October 2001 to January 2007 in order to work with a wider range of wave heights (during the winter 2001-2002 the $\mathrm{H}_{\mathrm{s}}$ reached the highest values measured in the region).

The corrected wave conditions during the study period are presented in Fig. 5. The wave height time series shows a cyclic behaviour, with storm periods (October-April) separated by periods of low storm activity (May-October). The mean $\mathrm{H}_{\mathrm{s}}$ during the studied years was $0.75 \mathrm{~m}$ and the averaged peak period T was $5.9 \mathrm{~s}$. The two most energetic periods affecting the beaches were from November 2001 to May 2002 and from October 2003 to April 2004.

Following Ojeda and Guillén (2008), significant storms affecting the Barcelona coast are those with $\mathrm{H}_{\mathrm{s}}$ higher than $2.5 \mathrm{~m}$ during the peak of the storm and a minimum duration of $12 \mathrm{~h}$ with $\mathrm{H}_{\mathrm{s}}$ greater than $1.5 \mathrm{~m}$. If the interval between two consecutive storms is lower than $6 \mathrm{~h}$, they are considered as a single double-peaked storm. The significant storm events affecting the coast of Barcelona during the study period are marked in Fig. 5 and the characteristics of a selection of these events (the ones most commented on in the text) are displayed in Table 2. Events i and ii represent the two major storms of the study period: two consecutive intensity peaks from the ENE direction separated by a short time lapse.

The root mean squared wave height at breaking $\left(\mathrm{H}_{\mathrm{b}}\right)$ was calculated using linear wave theory and assuming that it is proportional to the water depth,

$\mathrm{H}_{\mathrm{b}}=\left(\mathrm{H}_{\mathrm{rms} 0}^{2} c_{\mathrm{g}, 0} \cos \left(\theta_{0}\right)\right)^{0.4}\left(\mathrm{Y}_{\mathrm{b}} / \mathrm{g}\right)^{0.2}$,

where $\mathrm{H}_{\mathrm{rms}}$ is the offshore root mean squared wave height, $\mathrm{c}_{\mathrm{g}, 0}$ is the deep water wave group velocity, $\theta_{0}$ is the offshore wave angle, $\mathrm{Y}_{\mathrm{b}}=0.5$ is the ratio of wave height to water depth for breaking waves and $g$ is the acceleration of gravity. Alongshore sediment transport was estimated with the CERC formula, adapted for deepwater wave quantities (following Ashton and Murray (2006) formulation),

$\mathrm{Q}_{\mathrm{s}}=\mathrm{K}_{2} \mathrm{H}_{0}^{12 / 5} \mathrm{~T}^{1 / 5} \cos ^{6 / 5}\left(\theta_{0}-\Phi\right) \sin \left(\theta_{0}-\Phi\right)$,

where $\mathrm{H}_{0}$ is the deepwater significant wave height, $\mathrm{T}$ is the wave period, $\Phi$ is the shoreline orientation and $K_{2}$ is given by

$\mathrm{K}_{2}=\mathrm{K}_{1}\left(\left(\mathrm{~g} \mathrm{Y}_{\mathrm{b}}\right)^{1 / 2} / 2 \pi\right)^{1 / 5}$

Here $K_{1}$ is the CERC empirical constant, which describes the sediment properties; and a value $\mathrm{K}_{1}=0.2$ is taken, in the range of values recommended in the literature.

\section{Alongshore uniform behaviour}

Alongshore-averaged cross-shore locations of the bars $\left[\mathrm{X}_{\mathrm{y}}(\mathrm{t})\right]$ in relation to the reference shoreline are given for both beaches in Fig. 6 . In general, the alongshore-averaged location of the bar at La Barceloneta was further offshore and showed a larger variability than that at Bogatell (the corresponding standard deviations were $15.28 \mathrm{~m}$ and $11.48 \mathrm{~m}$, respectively).

The short-term behaviour of $\left[\mathrm{X}_{\mathrm{y}}(\mathrm{t})\right]$ at Bogatell and La Barceloneta showed some similarities, with migration taking place in the same direction (onshore/offshore) during the most important stormy periods. Three major periods of offshore bar migration were observed
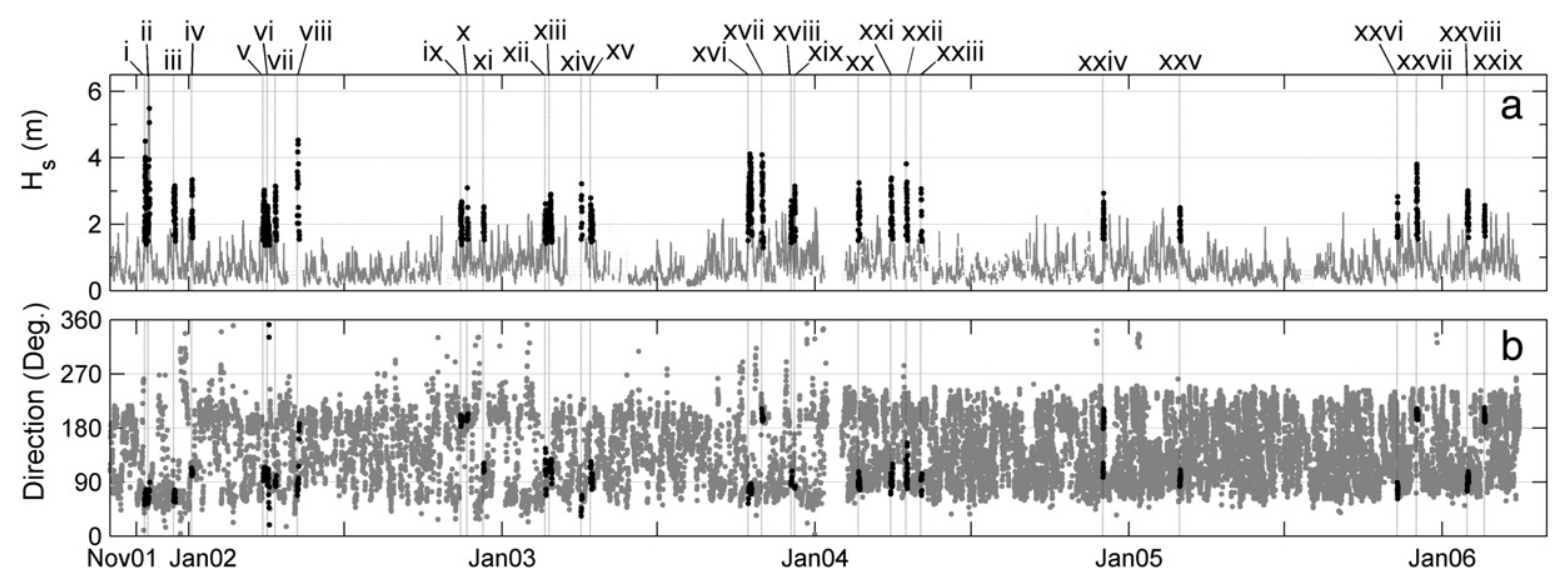

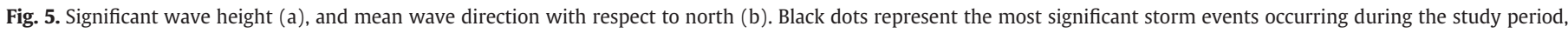

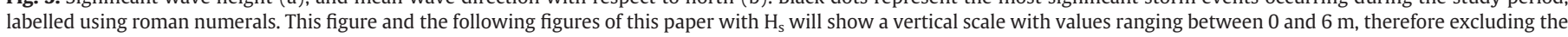
4 values of $\mathrm{H}_{\mathrm{s}}>6 \mathrm{~m}$ occurring during Event ii $\left(\mathrm{H}_{\mathrm{s}}=6.8,8.1,10.4\right.$ and $\left.10.5 \mathrm{~m}\right)$. 
Table 2

Characteristics of the storms mentioned in the text.

\begin{tabular}{|c|c|c|c|c|c|}
\hline Event & Initial date & $\begin{array}{l}\text { Mean } \mathrm{H}_{\mathrm{s}} \\
(\mathrm{m})\end{array}$ & $\begin{array}{l}\text { Max. } H_{s} \\
(\mathrm{~m})\end{array}$ & $\begin{array}{l}\text { Mean wave direction } \\
\text { with respect to north }\end{array}$ & $\begin{array}{l}\text { Duration } \\
\text { (h) }\end{array}$ \\
\hline i & 10-Nov-01 & 2.6 & 4.5 & $67^{\circ}$ & 57 \\
\hline ii & 14-Nov-01 & 3.2 & 10.5 & $69^{\circ}$ & 51 \\
\hline iii & 14-Dec-01 & 2.5 & 3.2 & $68^{\circ}$ & 51 \\
\hline $\mathrm{v}$ & 28-Mar-02 & 2.2 & 3.0 & $105^{\circ}$ & 59 \\
\hline vi & 02-Apr-02 & 1.8 & 2.6 & $111^{\circ}$ & 59 \\
\hline vii & 11-Apr-02 & 2.3 & 3.2 & $88^{\circ}$ & 34 \\
\hline viii & 07-May-02 & 2.8 & 4.5 & $109^{\circ}$ & 60 \\
\hline xii & 20-Feb-03 & 1.9 & 2.6 & $107^{\circ}$ & 30 \\
\hline xiii & 24-Feb-03 & 2.1 & 2.9 & $114^{\circ}$ & 82 \\
\hline xiv & 03-Apr-03 & 2.3 & 3.2 & $56^{\circ}$ & 27 \\
\hline $\mathrm{xv}$ & 14-Apr-03 & 2 & 2.8 & $100^{\circ}$ & 67 \\
\hline xvi & $15-O c t-03$ & 2.9 & 4.1 & $77^{\circ}$ & 100 \\
\hline xvii & $30-$-Oct-03 & 2.7 & 4.1 & $198^{\circ}$ & 44 \\
\hline$x x$ & 20-Feb-04 & 2.4 & 3.3 & $88^{\circ}$ & 44 \\
\hline $\mathrm{xxi}$ & 29-Mar-04 & 2.4 & 3.4 & $92^{\circ}$ & 58 \\
\hline xxii & 15-Apr-04 & 2.4 & 3.8 & $101^{\circ}$ & 45 \\
\hline xxiii & 03-May-04 & 2.2 & 3.1 & $88^{\circ}$ & 33 \\
\hline xxiv & 01-Dec-04 & 2.1 & 2.9 & $169^{\circ}$ & 27 \\
\hline $\mathrm{xxv}$ & 01-Mar-05 & 2 & 2.5 & $96^{\circ}$ & 24 \\
\hline xxvii & 02-Dec-05 & 2.6 & 3.8 & $201^{\circ}$ & 38 \\
\hline xxviii & 30-Jan-06 & 2.4 & 3.0 & $94^{\circ}$ & 39 \\
\hline xxix & 19-Feb-06 & 2.1 & 2.6 & $201^{\circ}$ & 19 \\
\hline
\end{tabular}

at both beaches in the winter of 2001-2002 (Events i to iii), in February 2003 (during Event xii and some prior minor storms occurring right after the erosion of the nourishment) and in the winter of 2003-2004, during Events xvi and xvii. In particular, the largest bar migration observed in the study period occurred during Events i to iii, when both bars migrated offshore, approximately $70 \mathrm{~m}$ at La Barceloneta and more than $30 \mathrm{~m}$ at Bogatell. After these three relatively sudden episodes of offshore migration, the barlines showed slower onshore migration. The wave height under which onshore migration occurred depended on the bar dimension relative to the water depth above it. The accumulated effect of Events v, vi and vii caused onshore bar movements of about $20 \mathrm{~m}$ at La Barceloneta and Bogatell. During Events xiii and xiv and the stormy conditions occurring in between, the bars also migrated about $20 \mathrm{~m}$ onshore at both beaches. Finally, onshore migration also occurred gradually around Events xxiv and xxv, with an overall onshore migration during the winter 2004-2005 of more than $30 \mathrm{~m}$ at both beaches. However, there were also some periods when the bars at both beaches showed a different behaviour. For instance, Events xxii and xxiii caused a clear offshore bar migration at Bogatell, while La Barceloneta did not show an evident response. In contrast, during Events xxviii and xxix and the post-storm conditions, the bar at La Barceloneta migrated offshore systematically, while that of Bogatell showed both onshore and offshore migration. The bars at La Barceloneta and Bogatell also presented a clear similitude on their monthly-averaged cross-shore locations (Fig. 7) with a significant correlation coefficient $\left(r^{2}\right)$ of 0.66 .

As shown in the previous paragraph, the alongshore uniform behaviour of the bars varied over a range of timescales. Fig. 8 presents the time series of the cross-shore locations decomposed into interannual $\left[\mathrm{X}_{\mathrm{ia}}(\mathrm{t})\right]$, seasonal $\left[\mathrm{X}_{\mathrm{s}}(\mathrm{t})\right]$ and weekly $\left[\mathrm{X}_{\mathrm{w}}(\mathrm{t})\right]$ components. The weekly component $\left[\mathrm{X}_{\mathrm{w}}(\mathrm{t})\right]$ shows the rapid changes in the bar location. The seasonal component $\left[\mathrm{X}_{\mathrm{s}}(\mathrm{t})\right]$ at both beaches shows a certain pattern with offshore migration during the first months of the winter season, followed by some onshore migration. This behaviour was very clear in Bogatell, with the only exception occurring in winter 2004-2005, when the offshore migration started during the previous summer. In La Barceloneta this behaviour was only visible during the winter seasons of 2001-2002, 2003-2004 and 2005-2006, the two first being the most energetic of the study period. The interannual component $\left[\mathrm{X}_{\mathrm{ia}}(\mathrm{t})\right]$ shows an onshore bar migration trend with an overall change in the bar location of about $30 \mathrm{~m}$ at La Barceloneta and about $20 \mathrm{~m}$ at Bogatell. At La Barceloneta, the interannual component explained $60 \%$ of the total variance of the alongshore-averaged location, while the weekly signal was responsible of $27 \%$. At Bogatell, the interannual signal was lower, accounting for only $34 \%$ of the total variance while the rapid weekly signal contributed to $50 \%$ of the total variance. The seasonal signal only explained around $15 \%$ of the total variance at both beaches.

\section{Alongshore non-uniform behaviour}

\subsection{Barline orientation}

The time-averaged barline during the study period was an approximately rectilinear line, oblique with respect to the reference shoreline, as shown in Fig. 9. This obliquity was more obvious at the
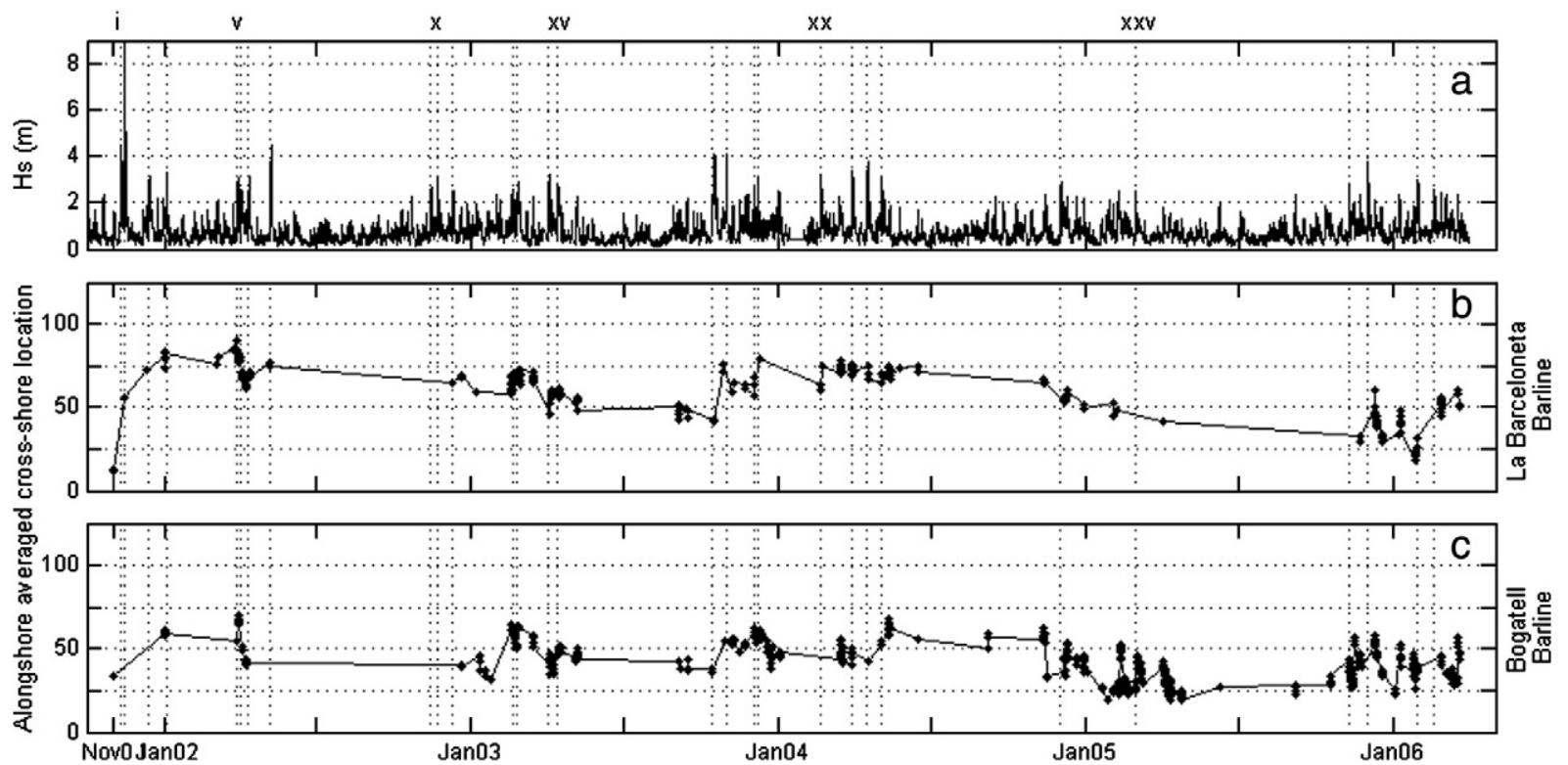

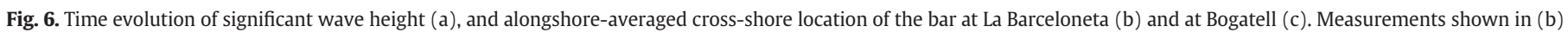
and (c) correspond to barlines containing more than $80 \%$ of the data and that were surveyed when $\mathrm{H}_{\mathrm{s}}$ was lower than $2.00 \mathrm{~m}$ at La Barceloneta and $1.75 \mathrm{~m}$ at Bogatell. 

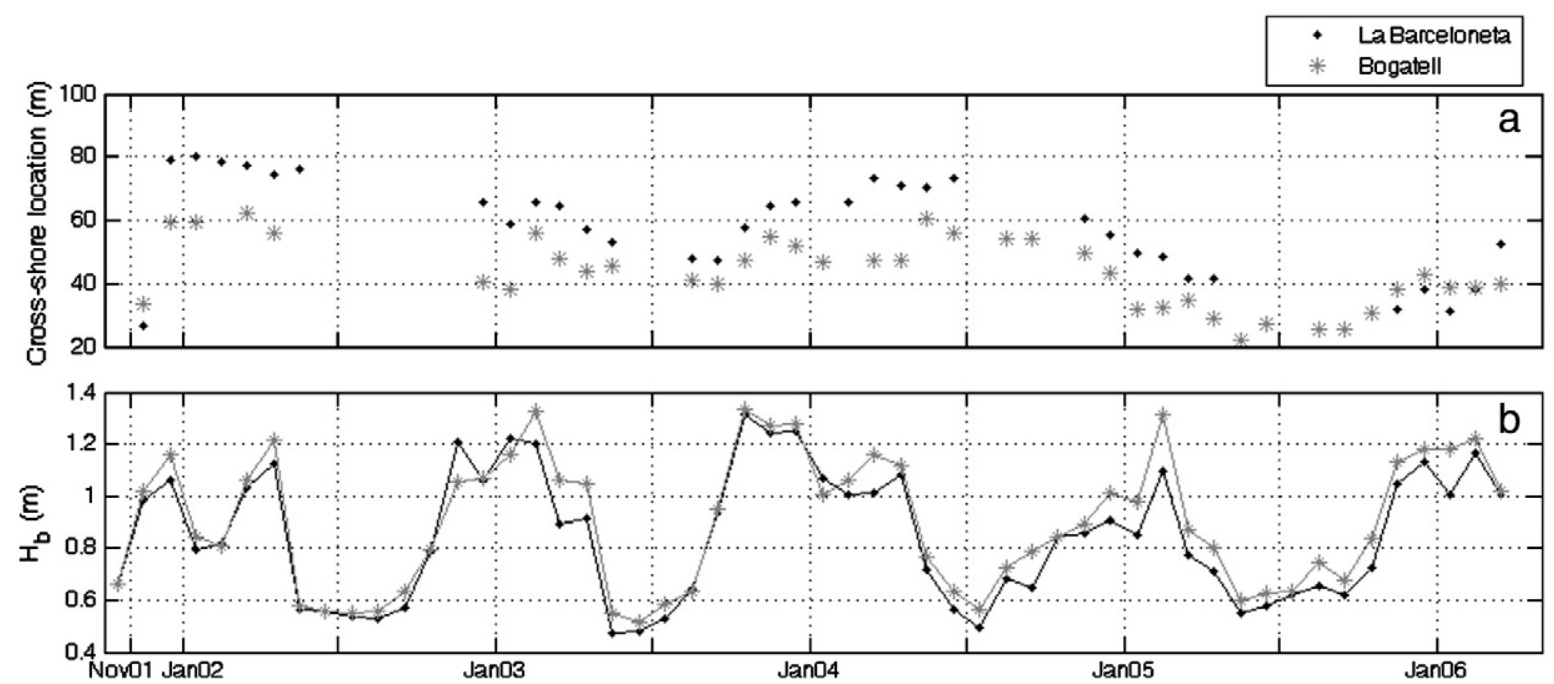

Fig. 7. Monthly- and alongshore-averaged cross-shore bar location at La Barceloneta and Bogatell (a), and monthly-averaged root mean squared wave height at breaking (b).

Bogatell beach, where the angle was approximately $5.3^{\circ}$, whilst at La Barceloneta beach it was $2.6^{\circ}$. Both were closer to the beach on their northern sides.

Fig. 10 presents the time series of the orientation of the barline and shoreline at each beach. The magnitude of the changes in orientation of the bar and the shoreline is equivalent for each of the beaches, with a range of angles of approximately $5^{\circ}$ at La Barceloneta and $10^{\circ}$ at Bogatell. The orientation of the shoreline and the barline at La Barceloneta showed a similar overall trend during the study period, with a gradual anticlockwise rotation (Fig. 10), which means that the obliquity of the bar with respect to the shoreline tended to remain constant. At Bogatell the shoreline and the barline did not show longterm changes in their orientation.

At shorter time scales, a visual evaluation of the changes in the orientation of the bar and the shoreline showed some analogies. In order to investigate quantitatively the potential coupling between barline and shoreline orientations, each barline orientation was compared to the nearest shoreline orientation in time, always maintaining the difference between the surveying dates lower than 3 days (i.e., barlines sampled 3 days before or 3 days after the shoreline). The squared correlation coefficient $\left(r^{2}\right)$ obtained for Bogatell was not significant at the 95\% confidence level. At La Barceloneta a $r^{2}$ of 0.57 was found (significant at
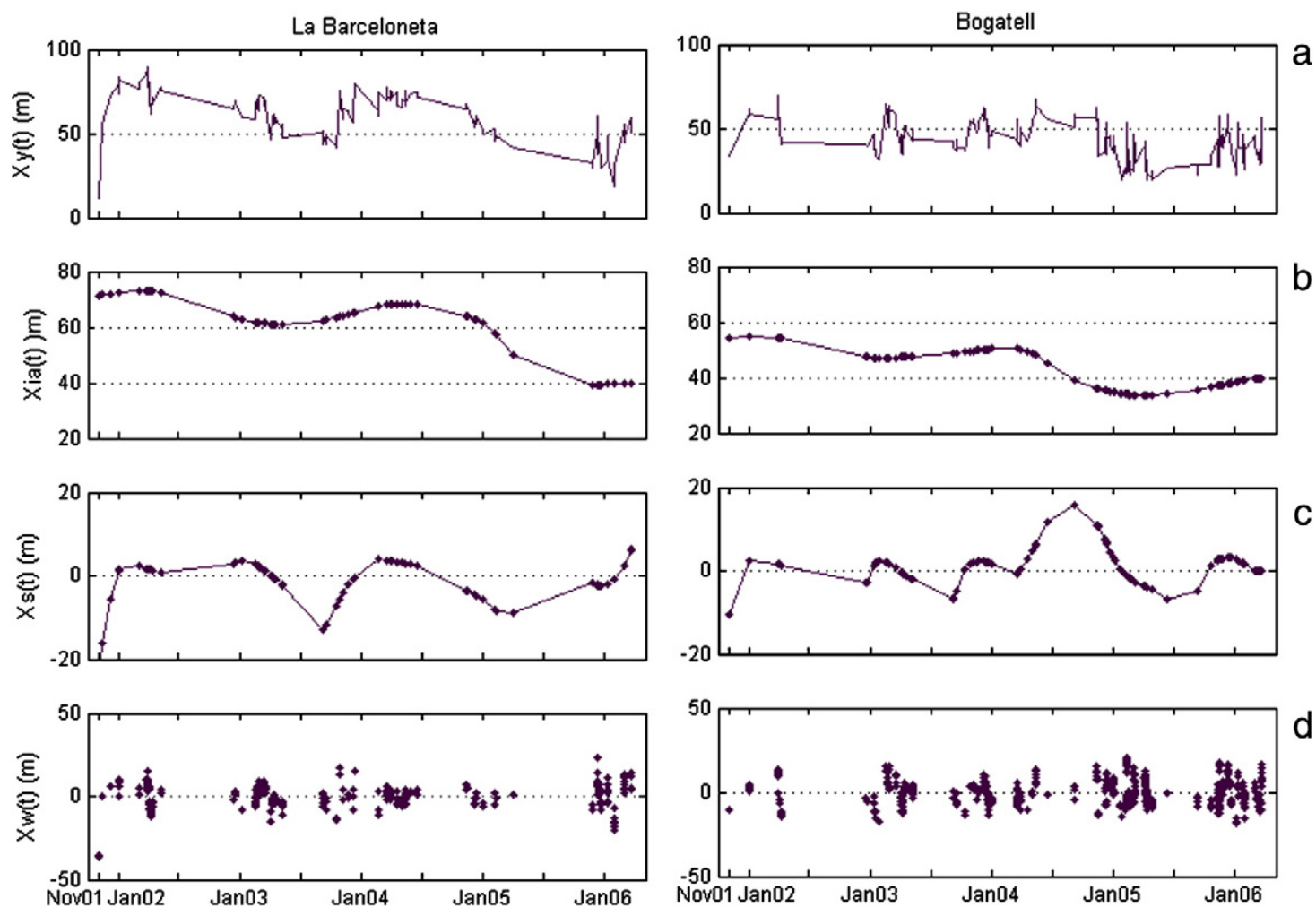

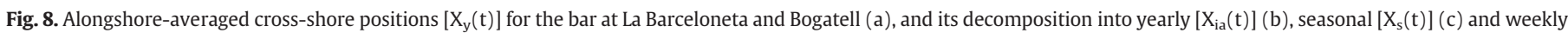
$\left[\mathrm{X}_{\mathrm{w}}(\mathrm{t})\right](\mathrm{d})$ components. 

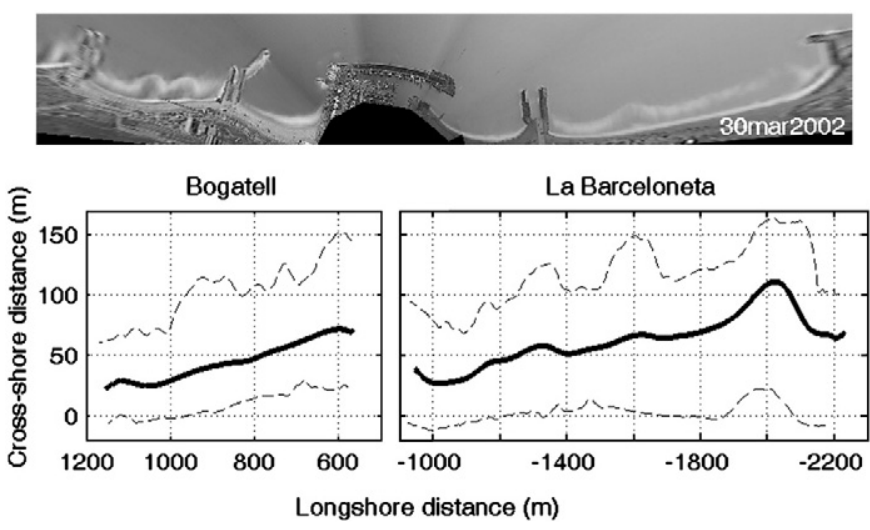

Fig. 9. Time-averaged barlines during the study period (dark solid line) and the most remote locations reached by the bars during the study period (lighter dashed lines). Cross-shore distances are relative to the reference shoreline.

the $99 \%$ confidence level), indicating a direct correlation between the bar and the shoreline orientations (Fig. 11). A clear exception to this behaviour occurred during the first half of 2003, when the bars at La Barceloneta and Bogatell turned clockwise whilst the shorelines of both beaches turned anticlockwise (Fig. 10). This behaviour was clearly influenced by the preceding artificial nourishment of the beach. In particular, in February 2003 the angle of the shoreline orientation decreased due to the retreat of the northern section of the beach. At the same time, the bar orientation increased because the southern bar section approached the beach slightly while the northern bar section moved slightly away from the beach.

\subsection{D bar morphology}

The morphological descriptor that we used to quantify the alongshore variability of the bars is their sinuosity (Fig. 12). Barcelona and Bogatell bars showed similar values of the sinuosity on average
( 1.06), although the time series of the bar sinuosity at Bogatell showed a larger number of changes. The highest sinuosity values of the bar at La Barceloneta were reached in February and October 2003, from December 2003 to April 2004, and in the winter of 2005-2006. At Bogatell the sinuosity showed several peaks, with the two maxima in March-May 2002 and in April-June 2004, and other minor peaks in February and October 2003 and in the winter of 2005-2006.

In general, the decreases of sinuosity were gradual and we could not associate them to specific storm events. For this reason, only the increases of sinuosity are analyzed in detail herein. Table 3 presents a list of all the eastern storms lasting more than 1.5 days and the corresponding changes in sinuosity (measured less than one day before and after the storm). A minor eastern storm that did not reach a maximum $\mathrm{H}_{\mathrm{s}}$ of $2.5 \mathrm{~m}$, occurring in 7-9 January 2006, is also included in Table 3 because it lasted more than 1.5 days and it produced a major increase in sinuosity. At Bogatell beach, every documented eastern storm produced an increase of sinuosity. La Barceloneta showed a smaller amount of changes in the sinuosity and only the eastern storms after January 2003 produced significant increases in this quantity. Notice that this relationship is bidirectional since every major increase of sinuosity $(>0.02)$ was also related to an eastern storm event (Fig. 12).

The three-dimensional behaviour of the beaches was analyzed in more detail with the temporal evolution of the complete barline $[\mathrm{X}(\mathrm{y}, \mathrm{t})]$ and shoreline positions together with the significant wave height during the study period (Figs. 13 and 14). Table 4 presents a relation of some relevant episodes clearly visible over time.

The effect of the November 2001 storms is clearly visible at both beaches, with a rotation of the shoreline and the barline. At La Barceloneta, a protuberance near the L-shape groin appeared on the barline. One of the most evident elements visible at the time evolution figures of both shorelines is the effect of the summer 2002 artificial nourishment as well as its erosion during winter 2003 (Figs. 13 and 14). After the retreat of the shorelines, particularly after Events xii and xiii, both bars became crescentic (see the associated increase in the sinuosity and the plan view of the rhythmic bar and beach in Fig. 15b

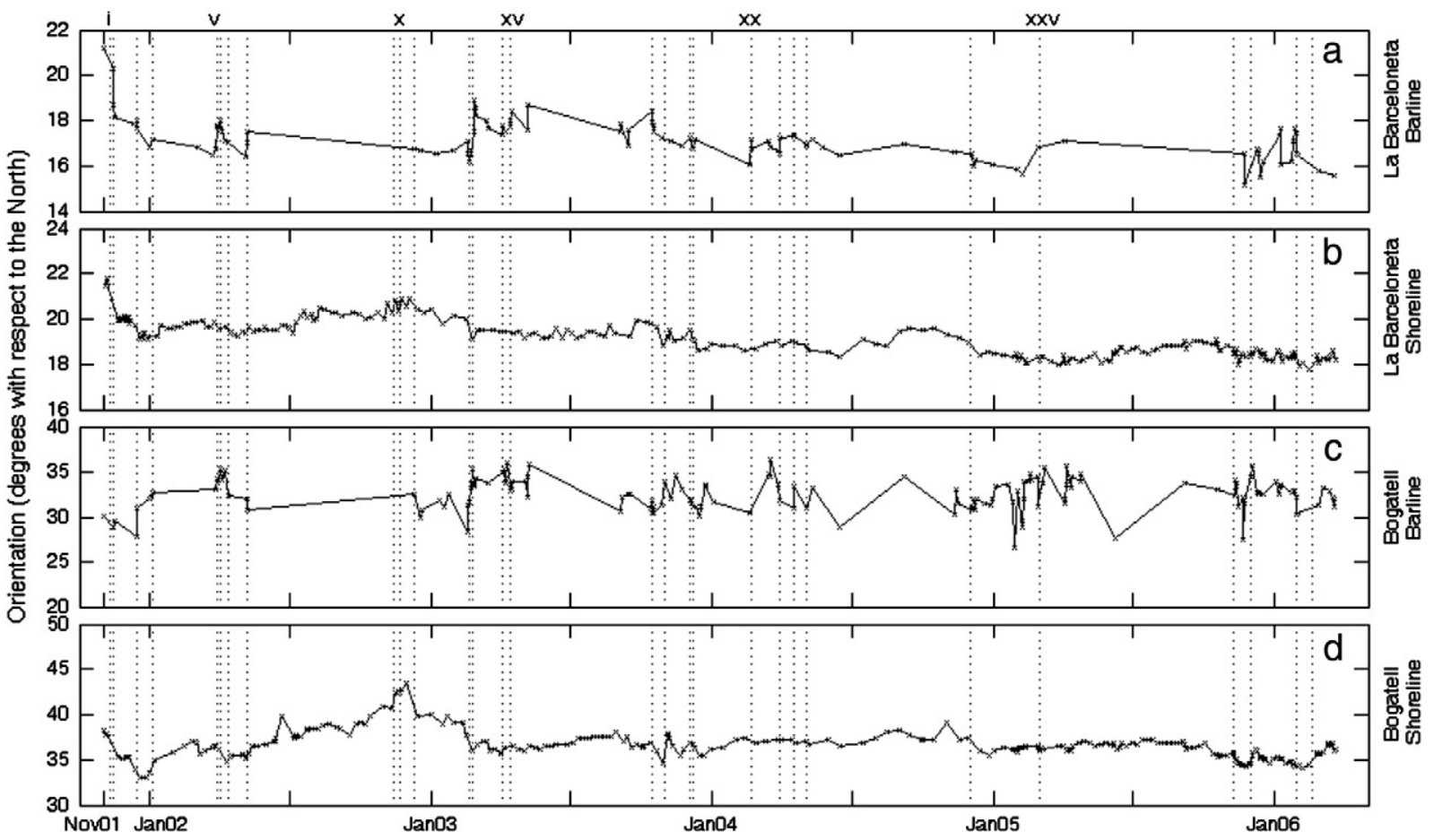

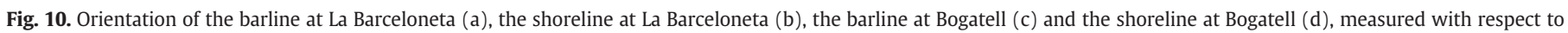
north. 

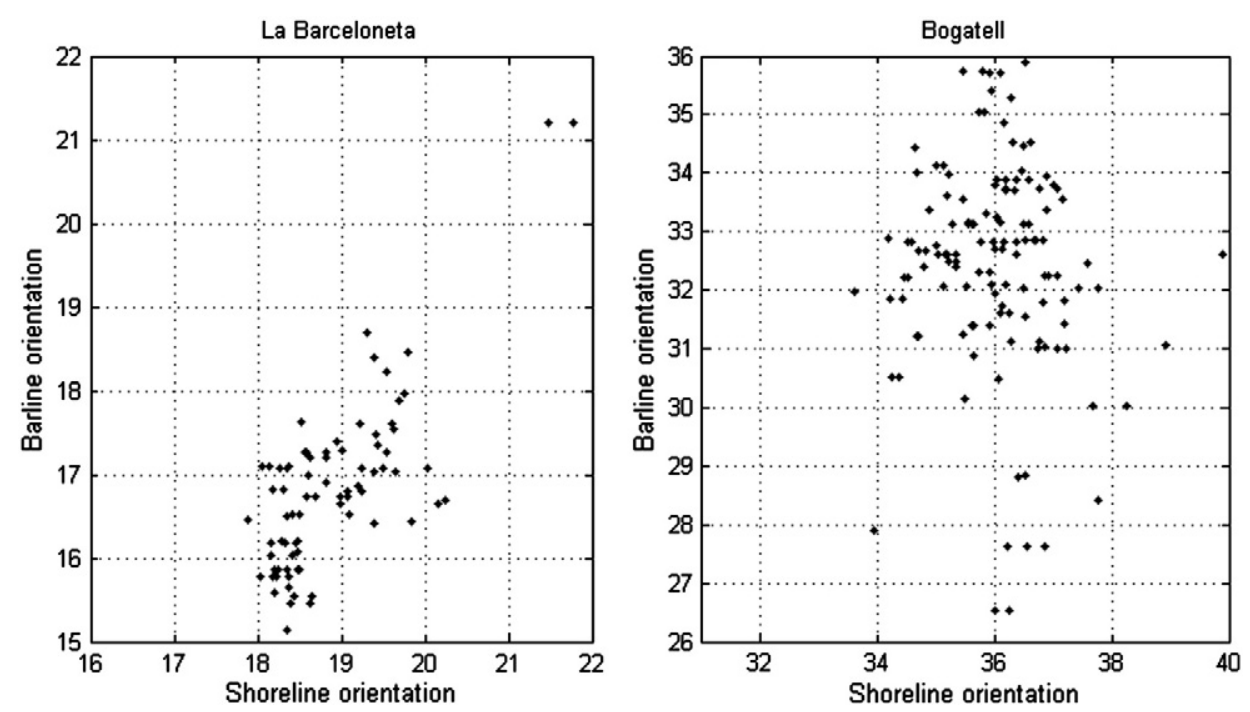

Fig. 11. Barline versus shoreline orientation during the study period at La Barceloneta (left) and Bogatell (right).

for La Barceloneta) and they gradually approached the coast during May-September 2003 (see Figs. 6 and 16b for Bogatell). Regarding the formation of crescentic shapes, two other clear examples with different wave lengths can be appreciated. The first one was after Event xvi, which caused significant offshore bar migration. At La Barceloneta beach, during the onshore migration that occurred subsequently, two sections of the rhythmic bar became attached to the shoreline, attaining a coupled configuration that would last for more than a year (with high sinuosity values, Fig. 12). This period of bar and shoreline coupling corresponds to the transverse bar and rip beach state (Fig. 15c) and apparently finished gradually ("apparently" because there were almost seven months without barlines available due to fair weather conditions). The second one took place after Events xxvii and xxviii, when new crescentic shapes with significantly smaller wave lengths appeared on both sand bars (compare Fig. 15c and d and Fig. 16c and d), implying again an increase in sinuosity.

It can be also seen from Figs. 13 and 14 that, compared to La Barceloneta, the Bogatell beach showed a more dynamic bar with more frequent changes in the bar morphology from linear to crescentic. In fact, at La Barceloneta the only reset of the bar due to stormy conditions occurred after Events i and ii, when the submerged sandbar experienced a strong offshore migration and adopted an almost linear configuration (Fig. 15a).

\section{Discussion}

The video system was used to monitor two of the artificial embayed beaches along the Barcelona city coast: La Barceloneta and Bogatell. The presence of a single submerged sandbar at these beaches is consistent with the slopes found in their submerged profiles (with a gradient of 0.031; Table 1), in agreement with the range (0.005-0.03) provided by Wijnberg and Kroon (2002) for subtidal bars in semiprotected and open coasts.

\subsection{Cross-shore bar migration}

In general terms, the migration of the submerged sandbars in the two studied beaches was coupled to the wave height conditions, with offshore migration occurring during the highest waves as observed in other areas (Sallenger et al., 1985). Also in agreement with previous studies, offshore bar migration showed a clear episodic character, whilst onshore bar migration was more gradual (Ruessink et al., 2009).

In a longer term perspective ( 4.5 years), the interannual component of alongshore-averaged cross-shore positions showed an onshore migration trend at both beaches (Fig. 8). The extremely energetic November 2001 storms (Events i and ii), with a return

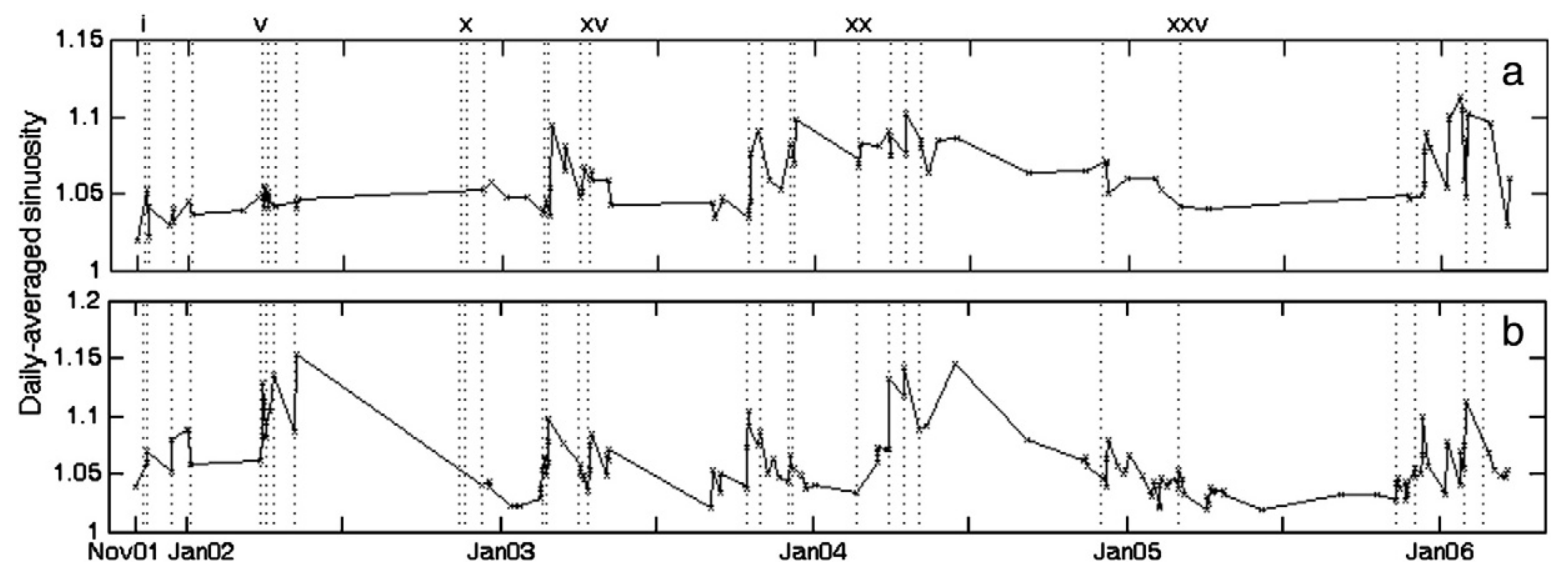

Fig. 12. Daily-averaged values of the sinuosity of the bar at La Barceloneta (a) and Bogatell (b). 
Table 3

Changes of sinuosity during the eastern storms of more than 1.5 days of duration.

\begin{tabular}{lll}
\hline Event $^{1}$ & Changes of sinuosity in BC & Changes of sinuosity in BO \\
\hline ii & -0.011 & 0.011 \\
iii & -0.008 & 0.027 \\
v & 0.006 & 0.068 \\
viii & 0.006 & 0.066 \\
xiii & 0.059 & 0.050 \\
xv & -0.001 & 0.039 \\
xvi & 0.042 & 0.054 \\
xx & 0.010 & NaN \\
xxi & 0.012 & 0.059 \\
xxii & 0.026 & 0.025 \\
(a) & 0.047 & 0.042 \\
xxviii & 0.056 & 0.058
\end{tabular}

(a) Eastern storm occurring from 7 to 9 January 2006 (it lasted $48 \mathrm{~h}$ and the mean direction was $96^{\circ}$ ), not documented in Table 2 because the maximum $\mathrm{H}_{\mathrm{s}}$ did not reach $2.5 \mathrm{~m}$.

1 Only the eastern storms with a standard deviation of the wave direction smaller than $50^{\circ}$ and with sinuosity data before and after the storm in at least one of the beaches are included.

period of 50 years (Gracia and Jiménez, 2004), prompted an unusual offshore bar migration and a sharp decrease of the wave height-water depth ratio over the bars. This ratio decrease favoured the subsequent onshore migration trend of the bars during the study period. This observed interannual onshore migration trend on Barcelona beaches is in agreement with the low-wave energy sandbar behaviour described for natural beaches (Pape et al., 2010). In addition, the cross-shore bar migration on Barcelona beaches partially resemble to the observed episodic NOM described for several natural multibarred beaches (Ruessink et al., 2009): rapid offshore bar migration triggered by extreme storms and prolonged onshore migration during subsequent low-energy conditions. In these multibarred beaches the prolonged low-energy conditions produce the decay of the outer bar and new wave events force the inner bar to the position of the former outer bar and the generation of a new bar ashore (Ruessink et al., 2009). In general, multibarred beaches affected by NOM (either interannual or episodic) have been observed in open coasts with significant tides, dominant alongshore transport and high sediment supply (Ruessink and Kroon, 1994; Ruessink et al., 2009; Shand et al., 1999). On the contrary, Barcelona beaches are single barred embayed beaches, subject to fetch limited incident waves, with an almost negligible tidal range and low sediment availability. It should be pointed out that we have not observed the development of a new bar or the decay of the existing bar (as occur in multibarred beaches with NOM). Consequently, the (same) bar migrates onshore/offshore following wave conditions and no long-term net migration pattern can be defined at the Barcelona beaches. Other single barred embayed beaches (i.e., Palm Beach and other Australian beaches) display an equivalent bar behaviour associated with storm events and the NOM is not observed (Ranasinghe et al., 2004). This suggests that the
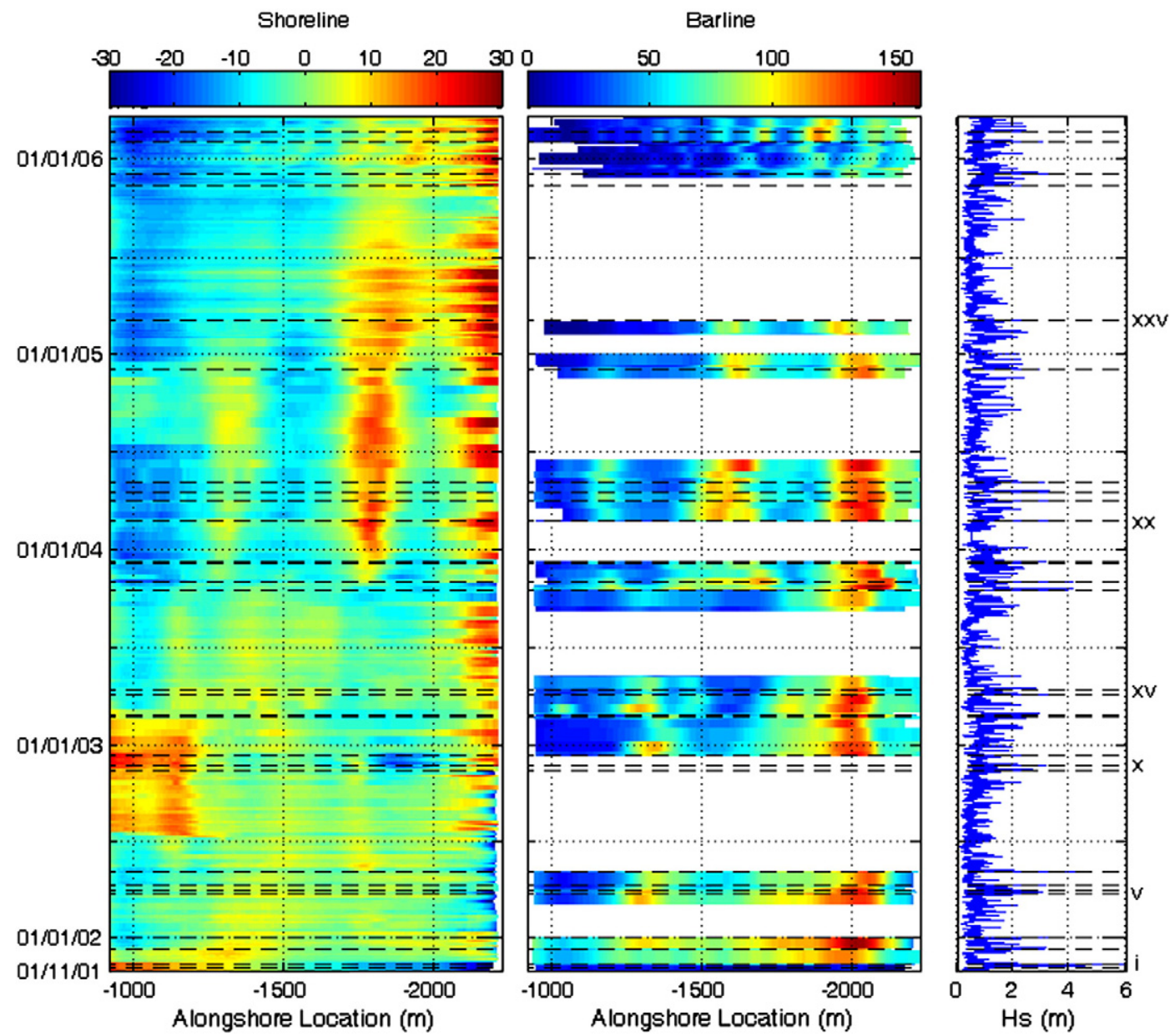

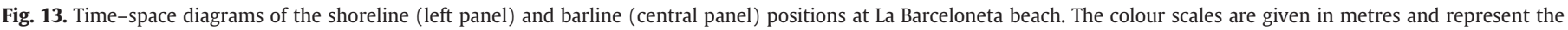

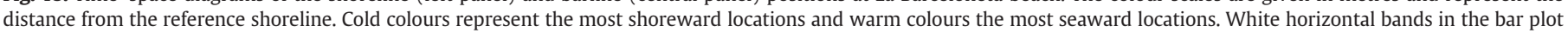
represent moments when no data were available. Significant wave height is given on the right panel. 


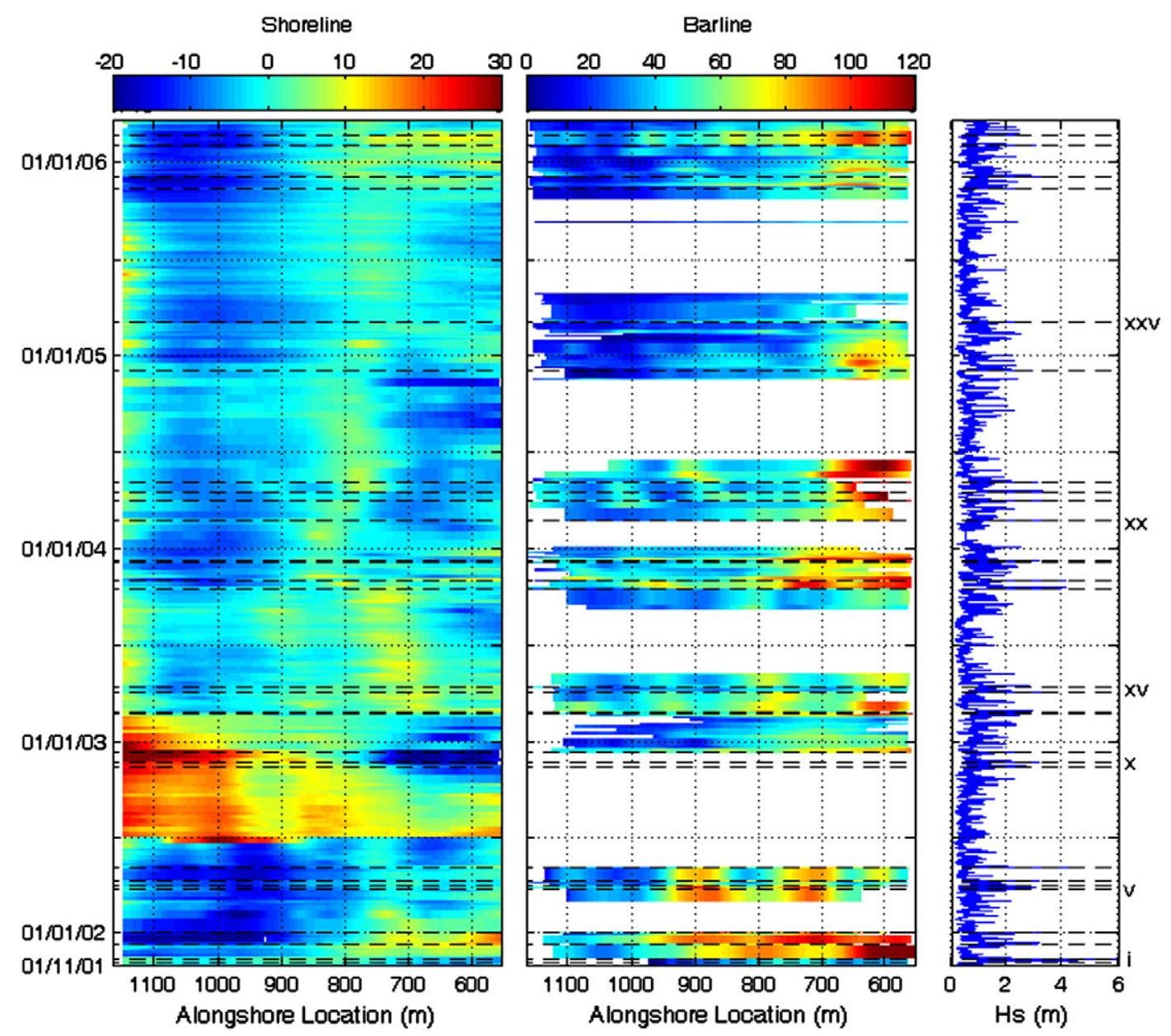

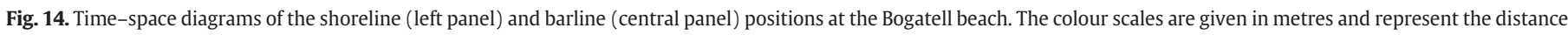

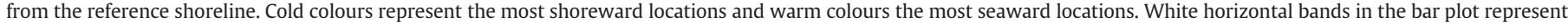
moments when no data were available. Significant wave height is given on the right panel.

absence of a net cross-shore bar migration in a long-term perspective might be a characteristic of single barred embayed beaches.

\subsection{Bar orientation}

The mean configuration of the submerged sandbars during the study period showed a certain obliquity with respect to the shoreline (the northern section of the bars usually placed in a position closer to the shore or even anchored to it; Fig. 9). Following Ashton and Murray (2006), the alongshore sediment transport was calculated for deepwater wave quantities and a yearly-averaged alongshore sediment transport ranging between 0.01 and $0.02 \mathrm{~m}^{3} /$ day in the southern direction was obtained at both beaches. This means that the bars are located progressively seaward in the dominant alongshore transport direction in agreement with observations in other Mediterranean areas (Guillén and Palanques, 1993). Thus the alongshore sediment transport can play a significant role in the barline orientation, as it does in the shoreline orientation. In fact, the orientation of the bar at La Barceloneta was coupled with the shoreline orientation at several time scales (e.g., Fig. 11). This allowed the correlations between the accumulated alongshore sediment transport occurring during different time periods (from 1 to 410 days) and the associated change in the bar orientation to be analyzed. Significant correlations at the $95 \%$ confidence level were found for time spans ranging from 10 to 70 days. This implies that the alongshore sediment transport can also play a significant role in the changes in the bar orientation for weekly to seasonal time scales. At the Bogatell beach the correlations of the barline orientation with the shoreline orientation or with the alongshore sediment transport were not significant. This may be

Table 4

Description of some relevant characteristics of the shoreline and the submerged sandbars visible at the time evolution figures.

\begin{tabular}{lllll}
\hline Time & La Barceloneta & & Bogatell \\
\cline { 2 - 3 } & Shoreline & Barline & Shoreline & Botation \\
\hline Events i and ii & Rotation & Offshore migration & & Offshore migration \\
Summer 2002 & Artificial nourishment & Notuberance formation & & Artificial nourishment \\
Feb. 2003 & Retreat N section & Crescentic & Ret visible & Crescentic \\
Event xvi & Megacusp & Crescentic & Megacusps & Crescentic \\
Events xxvii and xxviii & Megacusps & Crescentic & Crescentic \\
\hline
\end{tabular}



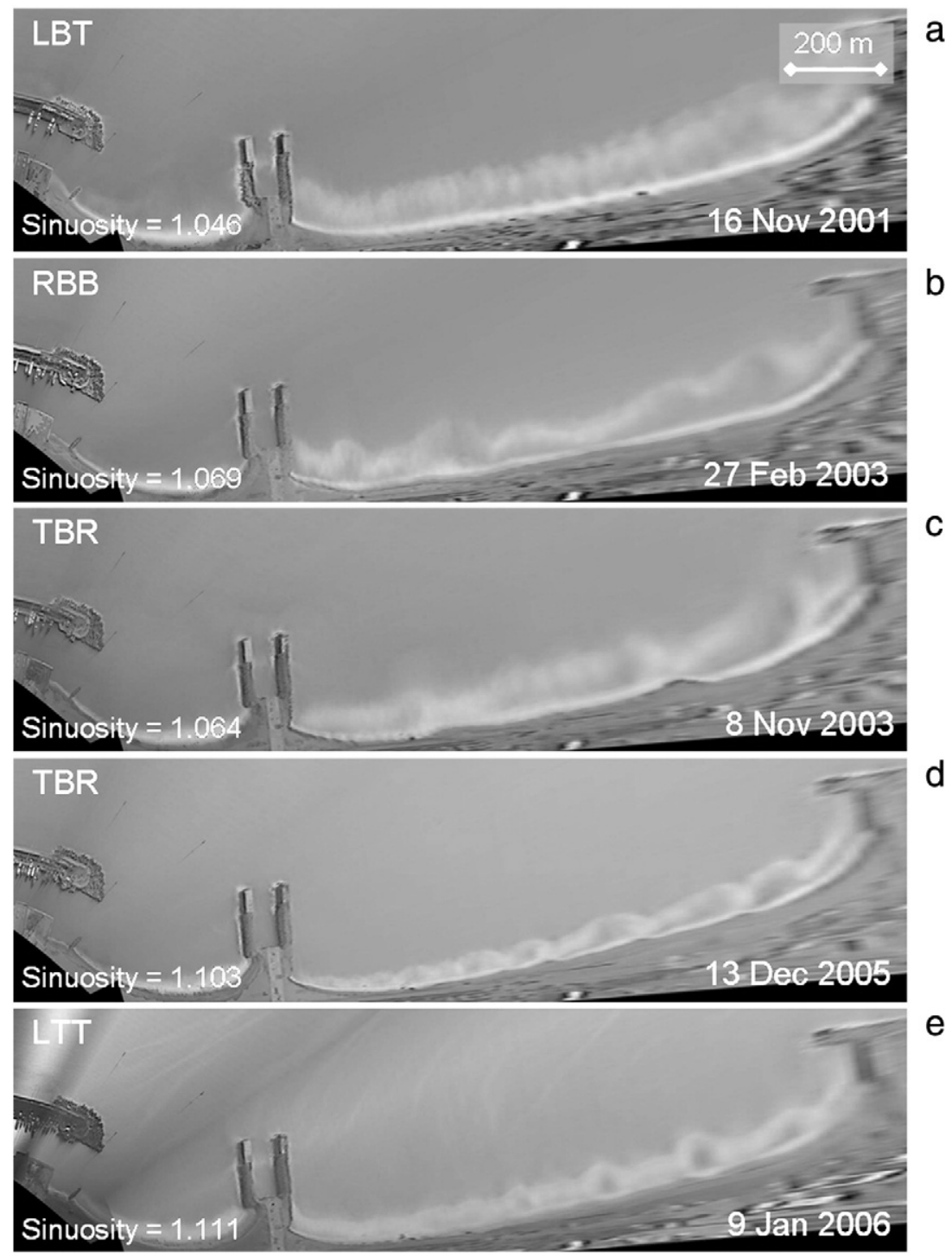

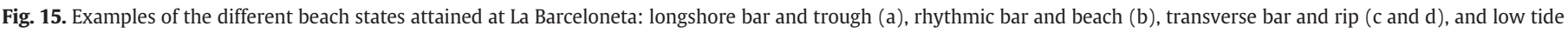
terrace (e). The corresponding values of bar sinuosity are given as examples.

due to the high level of indentation of the beach and the corresponding strong influence of the groins on the wave transformation.

\subsection{Morphodynamic beach states}

The submerged bars followed a general cyclic morphological behaviour, switching among the four intermediate morphodynamic states: longshore bar and trough associated with high-energy wave events, and rhythmic bar and beach, transverse bar and rip and low tide terrace associated with low-energy wave periods (Figs. 15 and 16). This cyclic behaviour is similar to that observed at Palm Beach (Ranasinghe et al., 2004), which is a natural beach comparable to Barcelona beaches (i.e., a microtidal, embayed beach of $2.5 \mathrm{~km}$ length).

The bars of the two Barcelona beaches displayed some differences. The bar at Bogatell, which is small and often terraced (i.e., without a bar trough; Fig. 3), underwent numerous changes in its morphodynamic state, generally switching between a linear and a crescentic bar (Fig. 14). The different configurations of the larger and better-developed bar at La Barceloneta were more long-lasting. For instance, during the study period the bar at Bogatell switched several times between the four morphodynamic states but the bar at La Barceloneta only underwent nearly a complete "reset" of the nearshore morphology once, associated with the highest-energy wave Events i and ii. At this beach, these events produced the offshore migration of the bar but they did not generate a completely linear bar. In particular, the protuberance in the southern section flattened only after several months of fair wave conditions in summer 2005 (Fig. 13). The existence of the L-shape groin partly explains the presence of such protuberance at La Barceloneta beach for a long period.

The bar at La Barceloneta remained arrested during long periods after high-energy events (e.g., during the whole 2004). Under these circumstances, the bar may be out of equilibrium with the prevailing wave climate because the energy level is too low to move the sand and force the bar any further in the accretionary sequence, as observed in other areas (Aagaard, 1998). The theoretical morphodynamic beach state predicted from wave conditions can differ from the real morphology of the beach during long periods of time in Barcelona beaches (Jiménez et al., 2008).

\subsection{Bar sinuosity}

Wright and Short (1984) established that under highly energetic wave conditions submerged sandbars migrate offshore and become shore-parallel. Under the subsequent lower energetic conditions the bar 

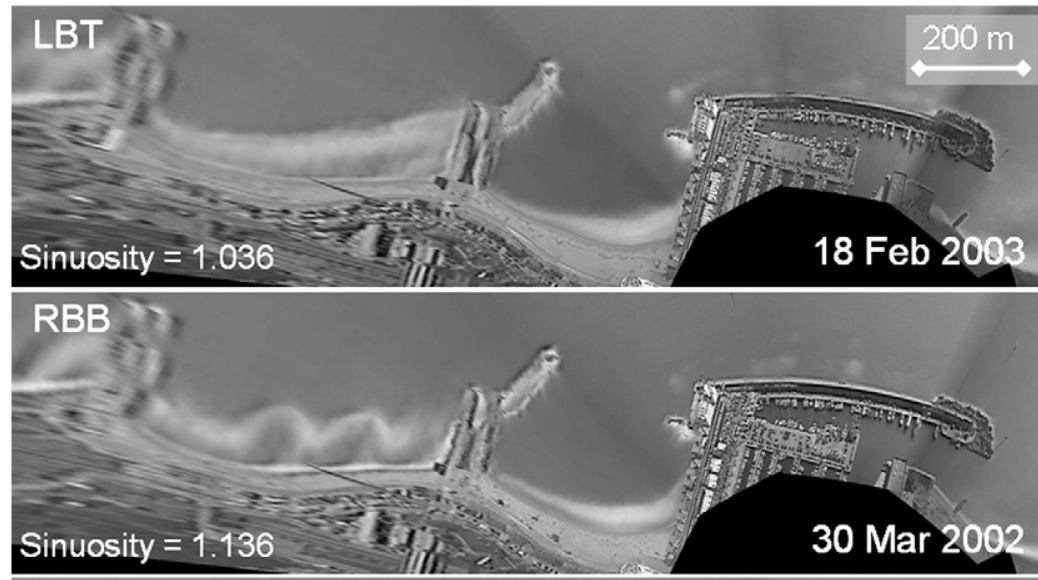

b

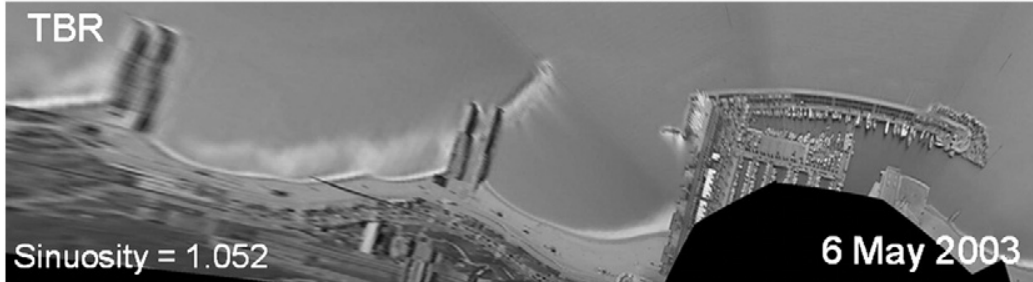

C
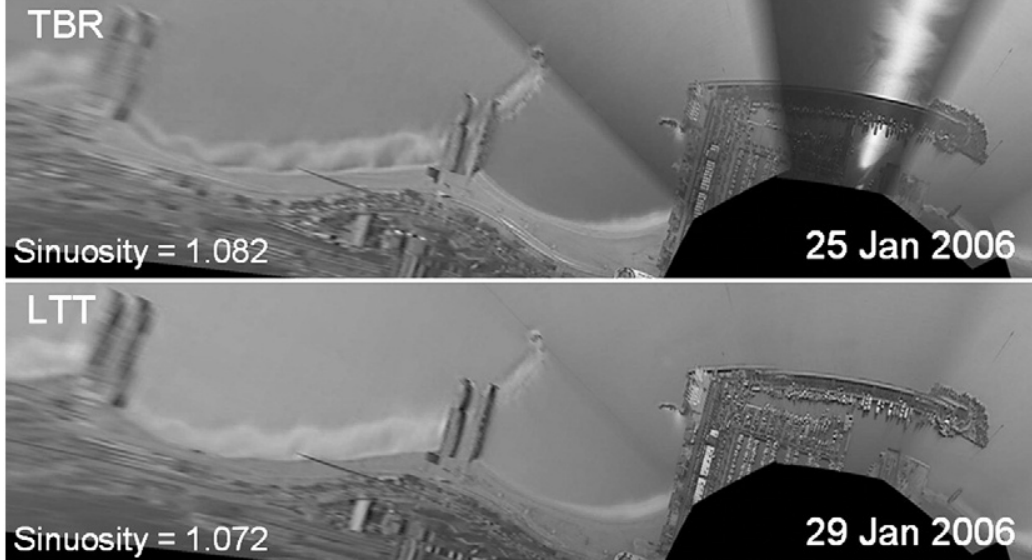

e

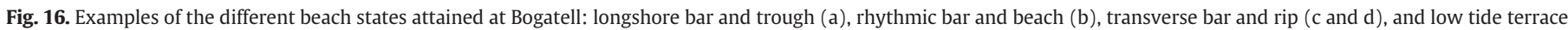
(e). The corresponding values of bar sinuosity are given as examples.

migrates onshore and becomes crescentic. The temporal resolution of our data set only allows us to compare the pre- and post-storm sinuosity values and analyse the overall storm effect on the bar sinuosity. Results show that all major increases in sinuosity (i.e., larger than 0.02) are related to eastern storms and, furthermore, that every eastern storm with duration longer than 1.5 days produced increases in sinuosity (Table 3). An exception occurred at La Barceloneta beach, where the bar showed smaller amounts of change in sinuosity and no significant changes of sinuosity were detected before February 2003 (another example of bar arrest, as described in the previous subsection). The fact that increases in sinuosity were associated with storm events can be interpreted as an up-state transition toward the RBB state. This was the dominant transition in Barcelona beaches because the complete reset occurred only during extreme wave events.

These sinuosity results are in accordance with the outcome of existing models for crescentic bar formation (e.g. Calvete et al., 2005; Klein and Schuttelaars, 2006). Firstly, the formation of rhythmic bars is predicted to occur under waves approaching from angles approximately normal to the beach. Eastern storms in Barcelona coast show angles of $68^{\circ}$ to $114^{\circ}$ from North (at $60 \mathrm{~m}$ depth) which means that their incidence is rather perpendicular to the shore. Secondly, models suggest that smaller bars located closer to the shore develop 3D morphologies more quickly than larger bars located farther away. This occurs because on the one hand less sediment transport is involved in the evolution of smaller bars and on the other hand less energy is required to affect bars at shallow waters. The fact that the less pronounced and smaller bar at Bogatell beach showed higher and more variable values of the sinuosity is in agreement with this model result.

In addition, at La Barceloneta and Bogatell beaches the occurrence of 3D longshore bars was also affected by the sediment availability, which enhances the appearance of crescentic shapes. For instance, two periods of high barline sinuosity that were observed at La Barceloneta (Fig. 12) could be related to an increase in the amount of sediment available in the submerged profile. The first one occurred in early 2003 , after the erosion of the nourished beach and a few storms at the end of the winter. The second one occurred in winter 2005-2006 and followed a retreat of the southern section of the beach together with the flattening of the southern-located megacusp. In this last case the eroded sand did not move alongshore (Fig. 13, shoreline) and some months later the sandbars were crescentic, with the lowest wavelengths observed during the study period (Fig. 13, barline). This is in accordance with observations in other nearshore regions of an increase in the bar three-dimensionality after the execution of a shoreface nourishment (Grunnet and Ruessink, 2005). In that case, the authors related the augmentation of the bar 3D morphology to the reduction in the water depth over the bar. 


\section{Conclusions}

La Barceloneta and Bogatell (Barcelona coast, NW Mediterranean) are artificial beaches protected by shore-perpendicular groins and have medium to coarse sediment and steep slopes. They often show a bar (or a terraced bar) and switch among the different intermediate beach states. As occur in natural beaches, their morphodynamic behaviour is mainly related to the wave climate affecting the coastal area. The arrest of the beach configuration at these beaches typically occurs during long periods, mostly associated with the long summer season typical of the Mediterranean wave conditions, when the wave energy is too low to cause significant sediment transport. In addition, there are other morphological changes caused by human interventions (e.g., artificial nourishments), which alter the beach configuration since it needs to readjust to a new equilibrium after the intervention.

The short-term cross-shore bar migration at the two studied beaches is qualitatively related to the wave height and the water depth where the bar is located (as reported in natural beaches). The changes in cross-shore bar location show a significant correlation in the two beaches at a monthly time scale. At an interannual time scale, La Barceloneta and Bogatell beaches display an onshore migration trend of the bar. This trend is due to the bias effect introduced by the unusual offshore bar migration caused by the extreme November 2001 storm at the beginning of the study period, which favoured the subsequent progressive onshore bar migration. However, no net onshore/offshore migration could be defined in the long-term with the present data set because there is no evidence of formation of new bars or offshore decay of existing bars. Therefore, the same bar moves onshore/offshore in response to wave conditions. In general, a net cross-shore bar migration as described in multibarred beaches cannot be defined in single barred beaches when there is no evidence of new bar formation.

The bars at both beaches are oblique with respect to the shoreline; their southern end being deviated offshore, following the net southern directed alongshore sediment transport. Furthermore, at weekly to seasonal time scales there is a significant correlation between the alongshore sediment transport and the bar orientation at La Barceloneta beach. This is coherent with the highly significant correlation detected between the orientations of the barline and the shoreline at this beach (i.e. the relative angle between the barline and the shoreline remains almost constant). Bogatell, a higher indented beach with a stronger influence of groins on the wave transformation, shows no relationship between the barline and the shoreline orientations or the alongshore sediment transport at different time scales.

The variability of the cross-shore bar position and the 3D bar morphology is dominated by different time scales in the two Barcelona beaches. The smaller terraced-bar at Bogatell beach undergoes a larger number of changes in its 3D morphology and the weekly component explains $50 \%$ of the total variance of the alongshore-averaged location. On the other hand, the larger and most developed bar at La Barceloneta beach displays less 3D morphological changes and the interannual component explains $60 \%$ of the total variance of the alongshoreaveraged location. Less-developed bars located close to the shore undergo more changes as less sediment is involved in their evolution and less energy is required to affect the bar at shallow waters. Also, extra sediment availability appears to be related to increases in the bar sinuosity. Finally, the bar sinuosity data presented in this study also shows that formation of rhythmic features always occurs under approximately normal waves approach, in agreement with the outcome of the models for crescentic bar formation.

\section{Acknowledgments}

This work was partially funded by the Spanish Ministry of Science and Technology within the project IMNOBE (CTM2009-11892). The work of E. Ojeda and F. Ribas is supported by the Spanish government through the Formación de Personal Universitario and Juan de la Cierva programs, correspondingly. Video and bathymetric data were provided by the Coastal Ocean Observatory at ICM (CSIC) in Barcelona (Spain).The authors would like to thank Dr. Gerben Ruessink for providing the BLIM software and for the revision of the manuscript, and Timothy Price and Gemma Ramaekers for helping with the data analysis. Finally, the comments and suggestions of two anonymous reviewers also improved the quality of this paper.

\section{References}

Aagaard, T., 1998. Nearshore bar morphology on the low-energy coast of northern Zealand, Denmark. Geografisk Tidsskrift 58, 27-31.

Aagaard, T., Davidson-Arnott, R., Greenwood, B., Nielsen, J., 2004. Sediment supply from the shoreface to dunes: linking sediment transport measurements and long-term morphological evolution. Geomorphology 60, 205-224.

Ashton, A.D., Murray, A.B., 2006. High-angle wave instability and emergent shoreline shapes: 1. Modeling of sand waves, flying spits, and capes. Journal of Geophysical Research 111, F04011.

Barusseau, J.P., Radulescu, M., Descamps, C., Akouango, E., Gerbe, A., 1994. Morphosedimentary multiyear changes on a barred coast (Gulf of Lions, Mediterranean Sea, France). Marine Geology 122, 47-62.

Bowman, D., Goldsmith, V., 1983. Bar morphology of dissipative beaches: an empirical model. Marine Geology 51, 15-33.

Calvete, D., Dodd, N., Falqués, F., van Leeuwen, S.M., 2005. Morphological development of rip channel systems: normal to near-normal wave incidence. Journal of Geophysical Research 110, C10006.

Certain, R., Barusseau, J.P., 2005. Sediment availability and conceptual models of sand bars morphodynamics for a microtidal beach (Sète, France). Proceedings of the 5th International Conference on Coastal Dynamics. Barcelona, Spain.

Gómez J., Espino, M., Puigdefabregas, J., Jerez, F., 2005. Xarxa d'Instrumentació Oceanogràfica i Meteorologica de la Generalitat de Catalunya (XIOM). Boies d'onatge dades obtingudes l'any 2004. Technical Report (catalan).

Gracia, V., Jiménez, J.A., 2004. Unexpected(?) response of infrastructures and beaches along the Spanish Mediterranean coast to the extreme storm of November of 2001. Proceedings of the 29th International Conference on Coastal Engineering, p. 16. Lisbon, Portugal.

Grunnet, N.M., Ruessink, B.G., 2005. Morphodynamic response of nearshore bars to a shoreface nourishment. Coastal Engineering 52, 119-137.

Guillén, J., Palanques, A., 1993. Longshore bar and through systems in a microtidal, storm-wave dominated coast: the Ebro Delta (NW Mediterranean). Marine Geology 115, 239-252.

Holman, R.A., Stanley, J., 2007. The history and technical capabilities of Argus. Coastal Engineering 54, 447-491.

Holman, R.A., Symonds, G., Thornton, E.B., Ranasinghe, R., 2006. Rip spacing and persistence on an embayed beach. Journal of Geophysical Research 111, C01006.

Jiménez, J.A., Guillén, J., Falqués, A., 2008. Comment to the article "Morphodynamic classification of sandy beaches in low energetic marine environment by GómezPujol, L., Orfila, A., Cañellas, B., Alvarez-Ellacuria, A., Méndez, F.J., Medina, R. and Tintoré, J. (Marine Geology, 242, 235-246, 2007)”. Marine Geology 255, 96-101.

Klein, M.D., Schuttelaars, H.M., 2006. Morphodynamic evolution of double-barred beaches. Journal of Geophysical Research 111, C06017.

Kuriyama, Y., 2002. Medium-term bar behavior and associated sediment transport at Hasaki, Japan. Journal of Geophysical Research 111 (C9), 3132.

Ojeda, E., Guillén, J., 2006. Monitoring beach nourishment based on detailed observations with video measurements. Journal of Coastal Research SI 48, 100-106.

Ojeda, E., Guillén, J., 2008. Shoreline dynamics and beach rotation of artificial embayed beaches. Marine Geology 253, 51-62.

Ojeda, E., Ruessink, B.G., Guillén, J., 2008. Morphodynamic response of a two-barred beach to a shoreface nourishment. Coastal Engineering 55, 1185-1196.

Pape, L., Plant, N.G., Ruessink, B.G., 2010. On cross-shore migration and equilibrium states of nearshore sandbars. Journal of Geophysical Research 115, F03008.

Plant, N.G., Freilich, M.H., Holman, R.A., 2001. Role of morphologic feedback in surf zone sandbar response. Journal of Geophyical Research 106, 973-989.

Ranasinghe, R., Symonds, G., Black, K., Holman, R., 2004. Morphodynamics of intermediate beaches: a video imaging and numerical modelling study. Coastal Engineering 51, 629-655.

Ribas, F., Ojeda, E., Price, T., Guillén, J., 2010. Assessing the suitability of video imaging for studying the dynamics of nearshore sandbars in tideless beaches. IEEE Transactions on Geoscience and Remote Sensing 48 (6), 2482-2497.

Rozynski, G., 2003. Data-driven modeling of multiple longshore bars and their interactions. Coastal Engineering 48, 151-170.

Ruessink, B.G., Kroon, A., 1994. The behaviour of a multiple bar system in the nearshore zone of Terschelling, The Netherlands - 1965-1993. Marine Geology 121, 187-197.

Ruessink, B.G., Pape, L., Turner, I.L., 2009. Daily to interannual cross-shore sandbar migration: observations from a multiple sandbar system. Continental Shelf Research 29, 1663-1677.

Sabatier, F., Provansal, M., 2000. Sandbar morphology of the Espiguette spit, Mediterranean Sea, France. Proceedings of the International Workshop on Marine Sandwave Dynamics, pp. 179-187. Lille, France.

Sallenger, A.H., Holman, R.A., Birkemeier, W.A., 1985. Storm induced response of a nearshore-bar system. Marine Geology 64, 237-257. 
Shand, R.D., Bailey, D.G., Shepherd, M.J., 1999. An inter-site comparison of net offshore bar migration characteristics and environmental conditions. Journal of Coastal Research 15, 750-765.

Short, A.D., 1985. Rip-current type, spacing and persistence, Narrabeen Beach, Australia. Marine Geology 65, 47-71.

Van Enckevort, I.M.J., Ruessink, B.G., 2003a. Video observations of nearshore bar behaviour. Part 1: alongshore uniform variability. Continental Shelf Research 23, 501-512.

Van Enckevort, I.M.J., Ruessink, B.G., 2003b. Video observations of nearshore bar behaviour. Part 2: alongshore non-uniform variability. Continental Shelf Research 23, 513-532.
Van Maanen, B., de Ruiter, P.J., Coco, G., Bryan, K.R., Ruessink, B.G., 2008. Onshore sandbar migration at Tairua Beach (New Zealand): Numerical simulations and field measurements. Marine Geology 253, 99-106.

Wijnberg, K.M., Kroon, A., 2002. Barred beaches. Geomorphology 48, 103-120.

Wijnberg, K.M., Terwindt, J.H.J., 1995. Extracting decadal morphological behaviour from high-resolution, long-term bathymetric surveys along the Holland coast using eigenfunction analysis. Marine Geology 126, 301-330.

Wright, L.D., Short, A.D., 1984. Morphodynamic variability of surf zones and beaches: synthesis. Marine Geology 56, 93-118. 